\title{
Trusting Trust
}

\author{
Deborah S. Gordon*
}

Deciding whether or not to trust... is like deciding whether or not to climb a tree, because you might get a wonderful view from the highest branch, or you might simply get covered in sap, and for this reason many people choose to spend their time alone and indoors, where it is harder to get a splinter. ${ }^{1}$

\section{INTRODUCTION}

Property owners often choose not to bequeath assets to their loved ones outright, but instead choose to leave their wealth in the care of trusted advisors who can carry forth the original owners' goals but also accommodate the survivors' changing needs. The vehicle for so doinga private donative trust - has been aptly characterized as a gift "projected on the plane of time and so subjected to a management regime." This

\footnotetext{
* Assistant Professor of Law, Drexel University School of Law. I am tremendously grateful to Al Brophy, Dan Filler, Richard Frankel, Alex Geisinger, Beth Haas, Aimee Kahan, Anil Kalhan, Rachel Lopez, Karen Sneddon, Pammela Saunders, Norman Stein, and Kevin Woodson for reading and commenting on earlier drafts of this Article. Thanks also to Mark Bernstein and the professional staff of the Drexel University Law School Library, who provided valuable research assistance and to Jaymes Fairfax-Columbo and Suraji Wagage, who provided additional research support.

1. Lemony SNicket, The Penultimate Peril 14 (2005).

2. Bernard Rudden, John P. Dawson's Gifts and Promises, 44 Mod. L. Rev. 610, 610 (1981) (book review); see also Thomas P. Gallanis, The New Direction of American Trust Law, 97 IowA L. REV. 215, 217-18 (2011) (describing the history and future of trusts); John H. Langbein, The Secret Life of the Trust: The Trust as an Instrument of Commerce, 107 YALE L.J. 165, 165 (1997) [hereinafter Langbein, Secret Life] (noting that trusts are our "characteristic device for organizing intergenerational wealth transmission"). Trusts provide a custodial and management mechanism by which one party, known as the settlor (or grantor, donor, or creator), empowers another, known as the trustee, to hold, administer, and distribute property for the benefit of one or more beneficiaries. Jeffrey A. Cooper, Empty Promises: Settlor's Intent, the Uniform Trust Code, and the Future of Trust Investment Law, 88 B.U. L. REV. 1165, 1166 n.1 (2008). While property owners can and often do serve as trustees for trusts they have established for themselves, this Article focuses on nonsettlor trustees. Moreover, although there are many different types of trusts, including charitable and business trusts, this Article focuses on the private donative trust, which is a wealth transfer mechanism usually used within a family. See John H. Langbein, The Contractarian Basis of the Law of Trusts, 105 YALE L.J. 625, 630-31 (1995) [hereinafter Langbein, Contractarian Basis]; see
} 
description is helpful because it highlights the trust's central, defining characteristics - divided ownership and temporal uncertainty-which also contribute to the trust's unique and sometimes perplexing challenges. ${ }^{3}$ As Denver-based estate planning lawyer John A. Warnick, founder of the Purposeful Planning Institute, has explained, trusts can do more than provide a mechanism for transmitting wealth efficiently by creating purposeful and collaborative legacies that address the human elements of estate planning. ${ }^{4}$

To achieve these purposes, however, several obstacles must be surmounted. First, the trust's creator, known as its "settlor," must select a person or entity to be the legal owner of the property and must decide what strictures to impose on (or freedoms to grant to) whomever is chosen; these planning decisions are made with the certain knowledge that circumstances surrounding the property and the beneficiaries will change. ${ }^{6}$ Second, as time passes, the trustee must decide how to organize investments and make distributions that satisfy often divergent goals and needs. $^{7}$ Third, the beneficiaries - who have less information than the

also LaWrence M. Friedman, Dead Hands: A Social History of Wills, Trusts, and INHERITANCE LAW 113 (2009) (describing two types of donative trusts: "caretaker," meaning that they are designed to terminate when the beneficiaries are able to care for themselves; and "dynastic," meaning that the settlor's primary motive is "to perpetuate and control the estate as long as possible").

3. See, e.g., 1 Austin Wakeman Scott, William Franklin Fratcher \& Mark L. ASCHER, SCOTT AND ASCHER ON TRUSTS $\S 1.1$ (5th ed. 2006) [hereinafter SCOTT ON TRUSTS]; Robert Cooter \& Bradley J. Freedman, The Fiduciary Relationship: Its Economic Character and Legal Consequences, 66 N.Y.U. L. Rev. 1045, 1048 (1991); Robert H. Sitkoff, An Agency Costs Theory of Trust Law, 89 CORNELL L. REV. 621, 623 (2004); Lee-Ford Tritt, The Limitations of an Economic Agency Cost Theory of Trust Law, 32 CARDOZO L. REV. 2579, 2587-88, 2614 (2011).

4. See Paul Sullivan, Focusing on the Human Element of Estate Planning, N.Y. TIMES (Nov. 7, 2014), http://www.nytimes.com/2014/11/08/your-money/estate-planning-with-the-human-elem ent.html.

5. SCOTT ON TRUSTS, supra note $3, \S 2.2 .1$.

6. John H. Langbein, Why Did Trust Law Become Statute Law in the United States?, 58 AlA. L. REV. 1069, 1078 (2007); see also Cooter \& Freedman, supra note 3, at 1046-48 ("Because asset management necessarily involves risk and uncertainty, the specific behavior of the fiduciary cannot be dictated in advance.... [U]nanticipated contingencies require continual recalculation to determine which course of action will be the most productive."); Melanie B. Leslie, Trusting Trustees: Fiduciary Duties and the Limits of Default Rules, 94 GEO. L. J. 67, 68-69 (2005) (explaining how a "settlor seeks a capable and conscientious individual or institution - an individual or institution that she trusts - to ensure the steady growth and continued availability of significant sums of money" even as she knows that future conflicts and questions may arise). For more practical articles describing the selection of trustees, see Jo Ann Engelhardt, Avoiding Problems with Trust Agreements and Fiduciary Administration, 49 No. 5 PRAC. LAW. 37, Oct. 2003, at 37, 38-40; Michael McGowan, Caveat Trustor: Avoiding Pitfalls Can Make Trusts More Worthy, A.B.A. J., Nov. 1993, at 97, 97; Mark S. Poker \& Amy S. Kiiskila, Prevention and Resolution of Trust and Estate Controversies, 33 ACTEC J. 262, 262 (2008).

7. Sitkoff, supra note 3, at 649-56; Tritt, supra note 3, at 2606-09. 
trustee-must be able to police the trustee's conduct to make sure she is not misusing the trust property for her own benefit or failing to take care of it properly. ${ }^{8}$ Fourth, and perhaps most importantly, private trust relationships are situated in a very specific context: among people who are related by blood or affection. ${ }^{9}$ In fact, trustees are frequently members of the family and beneficiaries in their own right. ${ }^{10}$ If the trust relationships are broken or damaged by means of a lawsuit or even just ongoing negative interactions, the results are not simply economic - they

8. Cooter \& Freedman, supra note 3, at 1053-56; Leslie, supra note 6, at 112-13.

9. See, e.g., Rollins v. Rollins, 755 S.E.2d 727 (Ga. 2014) (trust dispute between settlor's grandchildren and their father and uncle); Carter v. Carter, 965 N.E.2d 1146 (Ill. App. Ct. 2012), app. denied, 968 N.E.2d 1064 (Ill. 2012) (trust dispute between child and her step-mother); Wilbourn v. Wilbourn, 106 So. 3d 360 (Miss. Ct. App. 2012), reh'g denied (Sept. 25, 2012), cert. denied, 105 So. 3d 326 (Miss. 2013) (trust dispute between mother and her son); Shelton v. Tamposi, 62 A.3d 741 (N.H. 2013) (trust dispute among siblings); In re Matthew Larson Trust, 831 N.W.2d 388 (N.D. 2013) (trust dispute among siblings); In re Estate of Alden, 35 A.3d 950 (Vt. 2011) (trust dispute among children, step-mother, and step-siblings); In re Estate of Cooper, 913 P.2d 393 (Wash. Ct. App. 1996) (trust dispute among child, her father, and her father's second wife).

10. See infra note 21. Commentators often refer to the fact that trustee identity has shifted away from individuals and towards professional corporations. See, e.g., Gregory S. Alexander, A Cognitive Theory of Fiduciary Relationships, 85 CORnELL L. REV. 767, 775 (2000) (“Today, the vast majority of trusts are administered by large financial institutions, such as trust companies and trust developments of commercial banks.”); Tamar Frankel, Fiduciary Law, 71 CAL. L. REV. 795, 811 (1983) ("[I]n a predominantly mobile society, [family] fiduciaries have largely been replaced by commercial fiduciaries."); David Horton, Unconscionability in the Law of Trusts, 84 NOTRE DAME L. REV. 1675, 1681 (2009) ("[I]nstitutional trustees dominate the market for medium and larger estates.”); John H. Langbein, Questioning the Trust Law Duty of Loyalty: Sole Interest or Best Interest?, 114 YALE L.J. 929, 988-89 (2005) [hereinafter Langbein, Questioning] ("Professionalization has transformed trusteeship into a commercial relationship, now centered in the financial services industry, typically in bank trust departments."); Langbein, Contractarian Basis, supra note 2, at 638 ("Private trustees still abound, but the prototypical modern trustee is the feepaid professional [institution], whose business is to enter into and carry out trust agreements."); Sitkoff, supra note 3, at 633 ("The use of professional fiduciaries is reported to be on the rise."). To date, there have been few studies of who is actually serving as trustee, and those that do exist focus on data provided by institutional trustees. See Robert H. Sitkoff \& Max M. Schanzenbach, Jurisdictional Competition for Trust Funds: An Empirical Analysis of Perpetuities and Taxes, 115 YALE L.J. 356, 359 (2005) (describing study of jurisdictional competition for trust funds that derived empirical data from annual reports filed by institutional trustees); see also V. Gerard Comizio \& Jeffrey L. Hare, Regulatory Developments for Banks and Thrifts Conducting Trust and Fiduciary Activities, 59 Bus. LAW. 1299, 1300 (2004) (describing how banks have lost market share as other financial services companies began offering personal trust services). Otherwise, any information on how institutional trustees compare to individual trustees, family or professional, in number of trustee appointments or value of assets under management, appears to be anecdotal. See Tritt, supra note 3, at $2599 \mathrm{n} .86$ ("Short-term trusts of more modest means probably use individual trustees rather than corporate trustees."); see also Sitkoff, supra note 3, at $633 \mathrm{n} .57$ (describing empirical work yet to be done). And yet trustee identity can have important consequences. See Melanie B. Leslie, Common Law, Common Sense: Fiduciary Standards and Trustee Identity, 27 CARDOZo L. Rev. 2713, 2714 20 (2006); Paula A. Monopoli, Drafting Attorneys as Fiduciaries: Fashioning an Optimal Ethical Rule for Conflicts of Interest, 66 U. PITT. L. REV. 411, 413 (2005). Obtaining more concrete information on who is actually serving as trustee and how that matters is a project for another day. 
are practical, and they are emotional, too. ${ }^{11}$ For a trust to function well and with "purpose" then, the various participants must trust the trustee, and the trustee must earn and maintain that trust. ${ }^{12}$

In response to these challenges, scholars have offered alternative legal "symmetries and analogies" to help "illuminate" and "improve" how trusts and trust law are understood and function. ${ }^{13}$ Over the years, comparisons have been made to: the law of property and conveyances; ${ }^{14}$ the law of contracts; ${ }^{15}$ the law of organizations and agency; ${ }^{16}$ and even the law of speech and expression. ${ }^{17}$ This Article proposes an alternative approach to thinking about private trusts and their trustees by using as a touchstone the legal system's most highly scrutinized - and in an ideal form, trusted-decision-maker: the archetypal common law judge. Rather than discuss how courts and legislatures should view trustees, however, the Article focuses on how trustees, and the other parties to the trust relationship (including their respective counsel), should view themselves and each other. The Article's normative claim is that shifting the trust paradigm to envision a trustee as a judicial surrogate-an

11. See infra notes $125-36$ and accompanying text.

12. See Leslie, supra note 6 , at 113 . Of course, some trusts work well, at least from the settlor's perspective, where there is not trust between the trustee and beneficiaries.

13. Adam J. Hirsch, Freedom of Testation/Freedom of Contract, 95 MinN. L. REV. 2180, 2181 (2011); Langbein, Contractarian Basis, supra note 2, at 630. See infra notes 74-93 and accompanying text.

14. See Restatement (ThiRd) OF Trusts § 5(i) cmt. i (2003); Restatement (SECOND) OF TRUSTS $§ 197 \mathrm{cmt} . \mathrm{b}$ (1959); Austin W. Scott, The Nature of the Rights of the Cestui Que Trust, 17 Colum. L. REV. 269, 269-70 (1917); Gallanis, supra note 2, at 235; see also David Horton, Testation and Speech, 101 GEO. L.J. 61, 68-72 (2012) (describing property theory of testation); Hirsch, supra note 13, at 2181 ("The prevailing canon categorizes gratuitous transfers as a branch of property law-'family property law' ....").

15. See Langbein, Contractarian Basis, supra note 2, at 664; see also FREDERIC W. MAITLAND, EQUiTY: A COURSE OF LeCTURES 28 (John Brunyate rev. ed., 2d ed. 1936) (“'AA] trust generally had its origin in something that we can not but call an agreement."); Horton, supra note 10, at 1677 ("In the last decade, scholars and courts have begun conceptualizing the trust as a 'deal': a private agreement between the settlor and the trustee to manage the corpus.").

16. Sitkoff, supra note 3, at 623-24; see also Henry Hansmann \& Ugo Mattei, The Functions of Trust Law: A Comparative Legal and Economic Analysis, 73 N.Y.U. L. REV. 434, 435 (1998) (alluding to how common law systems for the law of trusts involve the "flexible rules" of agency).

17. See Horton, supra note 14, at 65; see also Mark Glover, A Therapeutic Jurisprudential Framework of Estate Planning, 35 SeAtTLE U. L. REV. 427, 455 (2012) ("By preparing an estate plan and implementing that plan through the execution of a will and other estate-planning documents, testators communicate to their friends, family, and community how they would prefer to dispose of their estates."); Deborah S. Gordon, Reflecting on the Language of Death, 34 SEATTLE U. L. REV. 379, 385 n.23, 429-31 (2011) (arguing that testamentary documents, including wills and trusts, should incorporate expressive language); Karen J. Sneddon, The Will as Personal Narrative, 20 ELDER L.J. 355, 366-409 (2013) (describing how wills contain and reflect the testators' voices and stories). 
arbiter, interpreter, problem-solver, mediator, and communicator-as opposed to an agent, partner, or contracting party will provide a way to build greater confidence in what might be called a trust community that originates with the settlor but is perpetuated by the trustee and beneficiaries as they interact on a daily basis. ${ }^{18}$ The ultimate goal of increasing trust is important because trust - or the simple act of relying on others to care for our interests ${ }^{19}$ - has been shown to enhance interpersonal relationships and business interactions by increasing satisfaction and reducing transaction costs. ${ }^{20}$ Trustees who already exhibit the judicial qualities described below-and doubtless there are many-do not find themselves in the type of embroiled disputes with suspicious beneficiaries that can be so destructive. A well-functioning trust relationship enhances the well-being of all its parties.

The Article proceeds in four parts. Part II sets forth the essential characteristics and tensions that define the private donative trust. After examining the duties and understandings that bind settlor, trustee, and beneficiaries, this Part describes in greater detail the trust's central challenges and the different legal frameworks that scholars have proposed in response. Part III explains why analogizing the trustee to the common law judge is useful for evaluating trust relationships and offers fresh insights for some of the private trust's internal governance

18. Recently, relying on Professor Tamar Frankel's seminal work on fiduciary law, a trio of scholars has proposed a fiduciary theory of judging. Ethan J. Leib, David L. Ponet, \& Michael Serota, A Fiduciary Theory of Judging, 101 CAL. L. REv. 699 (2013); see also TAMAR FRANKEL, FIDUCIARY LAW (2011); Frankel, supra note 10, at 795 (considering that fiduciaries "appear in a variety of forms"). But if applying principles of fiduciary law to the role of decision-maker helps refine how a judge should approach the judicial process, applying ideas about judging to the role of trustee is equally illuminating because these principles that bear on trustworthy decision-making can help elicit and manage settlor expectations, evaluate and accommodate beneficiary needs, and guide fiduciary conduct.

19. See Aiden Ward \& John Smith, Trust and Mistrust: Radical Risk Strategies in BUSINESS RELATIONSHIPS 8 (2003).

20. See, e.g., Leonardo Becchetti \& Giacomo Degli Antoni, The Sources of Happiness: Evidence from the Investment Game, 31 J. ECON. PSYCHOL. 498, 507 (2010) (using investment game to show correlation between how much trust one individual placed in another and trustor's selfdeclared happiness); John F. Helliwell \& Haifang Huang, How's the Job? Well-Being and Social Capital in the Workplace, 63 InDUS. \& LAB. REL. REV. 205, 220-22 (2010) (finding that workplace trust is "strong determinant" of job satisfaction and can allow companies "to reap rewards in some combination of . . l lower quit rates, lower monitoring costs, easier (and hence less expensive) hiring, and more effective effort from employees at all wage levels"); Yasuharu Tokuda, Seiji Fujii \& Takashi Inoguchi, Individual and Country-Level Effects of Social Trust on Happiness: The Asia Barometer Survey, 40 J. APPLIED SOC. PsYCHOL. 2574, 2585-89 (2010) (describing how Asian cross-national research revealed association between trust and happiness). See generally WARD \& SMITH, supra note 19, at 1-37 (describing how different types of "trust" function independently and together to enhance business relationships). 
dilemmas. Part IV discusses the foundational requirements for a trusted decision-making process: impartiality, competence, integrity, and candor. Part V shows how applying the judicial paradigm to the trust relationship has theoretical and practical implications for trust design and administration. For example, it supports the idea that trustees should disclose and explain their decision-making to the other parties affected by that process, not only for adversarial reasons, such as allowing beneficiaries to enforce their rights, but also for trust-enhancing reasons. This Part also applies the trustee-as-judge analogy to other key trust governance issues, including delegation of investment responsibilities and discretionary distribution standards, observing that some of the most respected rules follow a judicial model while some of the more controversial and highly criticized rules depart from it. Finally, even where the judicial analogy appears to fall short-because independence, a central feature of judicial legitimacy, is not required for trustees ${ }^{21}$ - the analogy is useful because it highlights some deep-seated flaws underlying traditional notions about how best to select trustees.

\section{PRIVATE Donative TRUSTS AND ThEIR DYNAMIC DYNASTIC TRIANGULAR LIVES}

The donative trust—or "use" as it was first called — developed back in the thirteenth century as a mechanism for transferring real estate that otherwise was subject to various legal restrictions on transfer. ${ }^{22}$ Because courts of law did not recognize these "illegal" transfers, a beneficiary who wanted to complain about how her trustee-her "faithless feoffee" 23 - was treating the property was forced to seek justice from the Chancellor, "who granted relief on the theory that he was "compelling

21. See, e.g., Donkin v. Donkin, 314 P.3d 780, 798 n.1 (Cal. 2013) (sibling both beneficiary and co-trustee); Smith v. SunTrust Bank, 754 S.E.2d 117, 120 (Ga. Ct. App. 2014) (daughter both beneficiary and trustee); Carter v. Carter, 965 N.E.2d 1146 (Ill. App. Ct. 2012), app. denied, 968 N.E.2d 1064 (Ill. 2012) (step-mother both beneficiary and trustee); Wilbourn v. Wilbourn, 106 So. 3d 360 (Miss. Ct. App. 2012), reh'g denied (Sept. 25, 2012), cert. denied, 105 So. 3d 326 (Miss. 2013) (son and mother both beneficiaries and co-trustees); In re Estate of Alden, 35 A.3d 950 (Vt. 2011) (step-mother both beneficiary and trustee); In re Estate of Cooper, 913 P.2d 393 (Wash. Ct. App. 1996) (father both beneficiary and trustee).

22. SCOTT ON TRUSTS, supra note $3, \S 1.4$; see also Sande Buhai, Lawyers as Fiduciaries, 53 ST. LouIS U. L.J. 553, 558 (2009) ('[T] he Anglo-American 'trust,' in which trustee is bound to beneficiary by fiduciary duty, evolved to permit circumvention of a variety of medieval property rules."). For example, such a legal restriction might be that the recipient was a member of the church and so could not own land. See SCOTT ON TRUSTS, supra note 3, § 1.3 at 11-12.

23. Langbein, Contractarian Basis, supra note 2, at 634. 
the trustee to act upon the dictates of his conscience", 24 and thereby "forc[ing] the trustee to abide by his pre-existing moral or ethical obligation." "25 In other words, the trustee may not have been breaking "the law," but she was violating an equitable code. ${ }^{26}$ This birth in courts of equity makes sense because the delegation of trust was something of a leap of faith. The property owner, knowing she could not hold and manage the property herself ad infinitum, would choose a trustee who would represent her interests after time had taken over. ${ }^{27}$

The balance of this Part explores the donative trust vehicle, the challenges it poses, and various responses to those challenges. Section A describes how creators struggle with designing trusts that balance flexibility and structure in order to anticipate future events and needs, without unnecessarily restricting the trustee's ability to respond and react. Section B describes the traditional fiduciary duties that apply to the trustee's conduct, including the duties of loyalty and care and the many subsidiary duties that fall under these more general umbrellas. Section C looks at the various ways legal theorists have proposed characterizing the donative trust to solve its central dilemmas of divided ownership and temporal uncertainty.

\section{A. Trusts' Challenges}

No property owner can predict perfectly how the years will affect her beneficiaries and her possessions. ${ }^{28}$ Beneficiaries' needs will change, for example, as the beneficiaries marry or divorce, start or lose a business, or develop or overcome an illness or addiction. Investments too will

24. Leslie, supra note 6, at 73 (quoting SCOTT ON TRUSTS, supra note 3, § 1).

25. Id. at 73; Henry E. Smith, Why Fiduciary Law Is Equitable, in PhilosophiCAL Foundations OF Fiduciary LAw 261, 263 (Andrew S. Gold \& Paul B. Miller eds., 2014) ("[E]quity courts were known as courts of conscience. Equity bore a close relation to natural law and natural justice, and moral norms infused all of its work."). Professor Smith's essay provides a comprehensive discussion of the history of equity and its role in combatting the problem of opportunism.

26. Smith, supra note 25 , at 13 ("As an outgrowth of equity, it is not surprising that fiduciary law is... morally inflected. But the connection is more than mere path dependence; it is functional."). Procedural rules too supported the trust's foundation in the courts of equity because those courts could hear testimony from interested parties whereas courts of law refused to do so. See Langbein, Contractarian Basis, supra note 2, at 635-36.

27. See Deborah A. DeMott, Beyond Metaphor: An Analysis of Fiduciary Obligation, 1988 DUKE L. J. 879, 881 ("The evolution of fiduciary obligation thus owed much to the situationspecificity and flexibility that were Equity's hallmarks.").

28. See Daniel B. Kelly, Restricting Testamentary Freedom: Ex Ante Versus Ex Post Justifications, 82 FORDHAM L. REV. 1125, 1160 (2013). 
change, for example, by under or over-performing, reacting to world events, or re-forming into a different shape altogether. How the settlor would want her gift over time to accommodate these endless permutations is difficult to anticipate and therefore to counsel, which is a particular problem in a legal realm where the typical court resolving such a dispute would prioritize the settlor's intention over all else. ${ }^{29}$ How does a property owner plan to achieve her purposes but retain the fluidity and flexibility to deal with the unanticipated?

There are two possible approaches to this planning dilemma, and most trust arrangements combine gradations of each. ${ }^{30}$ The first is to draft a trust agreement that provides the trustee with clear distribution standards, describes the settlor's primary concerns, and dictates responses to various contingencies that are likely to arise. In other words, this approach uses language as its primary tool. ${ }^{31}$ For example, a common directive in many trusts that benefit different classes of beneficiaries, such as a surviving spouse and descendants, is to prioritize distributions to one over the other. ${ }^{32}$ A trustee alternatively might be

29. See, e.g., Rollins v. Rollins, 755 S.E.2d 727, 730 (Ga. 2014) ("“T]he cardinal rule in trust law is that the intention of the settlor is to be followed."); Carter v. Carter, 965 N.E.2d 1146, 1152 (IIl. App. Ct. 2012), appeal denied, 968 N.E.2d 1064 (Ill. 2012) (“A court's primary concern in interpreting a trust instrument is to discover the intent of the grantor, which the court will effectuate if it is not contrary to law or public policy.") (citing Citizens Nat'l Bank of Paris v. Kids Hope United, Inc., 922 N.E.2d 1093, 1097 (Ill. 2009)); In re G.B. Van Dusen Marital Trust, 834 N.W.2d 514, 521 (Minn. Ct. App. 2013) ("A court's purpose in interpreting a trust agreement is to 'ascertain and give effect to the grantor's intent."' (quoting In re Stisser Grantor Trust, 818 N.W.2d 495, 502 (Minn. 2012))); Shelton v. Tamposi, 62 A.3d 741, 746 (N.H. 2013) (“[W] hen we construe a trust instrument, 'the intention of a settlor is paramount ...."' (quoting Appeal of Lowy, 931 A.2d 552, 556 (N.H. 2007))); Rachal v. Reitz, 403 S.W.3d 840, 842 (Tex. 2013) (“[W]e enforce trust restrictions on the basis of the settlor's intent."); see also Kelly, supra note 28, at 1134 ("American succession law privileges 'donor's intention' as the 'controlling consideration' in determining the meaning of a donative document." (quoting RESTATEMENT (THIRD) OF PROP.: WILlS AND OTHER DONATIVE TRANSFERS $\S 10.1(2003))$ ); Sitkoff, supra note 3, at 638 ("[T] subordinates the interests of the beneficiaries as residual claimants to the dead-hand interests of the settlor, an outgrowth of the frequently paternalistic function of the donative trust."); see also infra notes 74-78 and accompanying text. But see Gallanis, supra note 2, at 216 ("American trust law, after decades of favoring the settlor, is moving in a new direction, with a reassertion of the interests and rights of the beneficiaries.").

30. See, e.g., Leslie, supra note 6, at 89 ("Parties that cannot anticipate all potential agency cost problems rely on fiduciary duties as a substitute for express contract provisions.").

31. See Kristen E. Caverly, Help Clients Grant the Right Level of Trustee Discretion, 39 EsT. PLAN. 18, 19-28 (2012) (providing samples of language to guide trustee discretion); Benjamin H. Pruett, Tales from the Dark Side: Drafting Issues from the Fiduciary's Perspective, 35 ACTEC J. 331, 341-47 (2010) (same).

32. For examples of trust agreements that prioritize spousal interests, see Scanlon v. Scanlon, 993 N.E.2d 855 (Ohio Ct. App. 2013); In re Van Dusen, 834 N.W.2d 514 (Minn. Ct. App. 2013); O'Riley v. U.S. Bank, N.A., 412 S.W.3d 400, 408 (Mo. Ct. App. 2013), transfer denied, (Oct. 29, 
told: to distribute principal to a child for the purchase of a home or a business in the same manner that the trust's settlor would have done, were she living; to retain a particular asset for sentimental reasons, regardless of its change in value; to terminate a trust if it becomes too small to be economical; or to distribute income to a spouse in accordance with "the lifestyle to which she had become accustomed." Although a trustee and court might have to interpret these instructions, the document will provide guidance as to preferences so long as the parties are willing to bear the administrative costs of drafting for contingencies and so long as no unanticipated changes occur. ${ }^{33}$ But all the planning in the world still cannot control the future. ${ }^{34}$ If a trust expresses preference for a spouse, who turns out to have sufficient independent funds, to the detriment of an ailing child, the trustee would arguably be required to act in contravention of the settlor's unexpressed but probable intent and certainly not in all of the beneficiaries' best interests, unless the trust were judicially modified. ${ }^{35}$

Recognizing language's inadequacy and humans' inability to predict and plan for every contingency, the second approach to dealing with the imperfect foresight that accompanies a gift over time is to repose "absolute discretion" in a trustee. ${ }^{36}$ In other words, the trust agreement's distributive and investment directives would be more expansive, allowing the trustee flexibility to deal with whatever inevitable

2013). For an example of a trust agreement with language that does not express this priority, see $I n$ re Estate of Alden, 35 A.3d 950, 953-55 (Vt. 2011).

33. See, e.g., Frankel, supra note 10, at 813 ("[T] detailed prior agreement covering all possible discretionary uses of power over the life of the relation would not only be enormous, but also would probably exceed the benefits of the proposed relation. A more general document (whether a contract, trust, or charter) setting forth only the main purposes of the relation and the broad functions of the fiduciary would not impose such great transaction costs, but would less adequately prevent specific abuses of power."); Kelly, supra note 28, at 1158-61 (describing costs and contingencies); Leslie, supra note 10, at 2719 ("[Settlors and trustees] cannot draft agreements that accurately anticipate and resolve all future conflicts.").

34. Seth W. Krasilovsky, Exercising Discretion in Administering Discretionary Trusts, 36 EsT. PLAN. 32, 32 (2009).

35. While the trustee or beneficiaries might file a petition to modify or terminate the trust, doing so ordinarily requires a court proceeding and a finding that the trust's "material purposes" are no longer being served or its terms are "administratively inconvenient." See SCOTT ON TRUSTS, supra note 3, § 16.4; see also UNIF. TRUST CODE $\S \S 410-12$, 7C U.L.A. 164-68 (Supp. 2003); RESTATEMENT (THIRD) OF TRUSTS $\S \S 65-66$ (2003) (defining conditions for termination or modification of trusts); John H. Langbein, Mandatory Rules in the Law of Trusts, 98 Nw. U. L. REV. 1105, 1117-20 (2004) [hereinafter Langbein, Mandatory Rules] (discussing trust modification); Sitkoff, supra note 3, at 658-63 (same).

36. Edward C. Halbach, Jr., Problems of Discretion in Discretionary Trusts, 61 ColuM. L. REV. 1425, 1430-33 (1961); see also Krasilovsky, supra note 34, at 34-35 (providing examples of "absolute discretion" language). 
uncertainties time may engender. ${ }^{37}$ The settlor would choose a fiduciary that understood the settlor's goals and therefore, even without specific words of guidance in the document, would be able to act as the settlor's surrogate and administer the trust in accordance with her ideals. But reposing so much faith and flexibility in a trustee puts significant pressure on the fiduciary relationship and prompts questions for the trustee about whose needs should take priority. ${ }^{38}$ Does the trustee defer to what the settlor would have wanted or does the trustee prioritize a strategy that will best serve the beneficiaries? ${ }^{39}$ As inadequate as the first approach may seem, because of the costs associated with trying to anticipate what will happen in the future and the gaps and chinks that are likely to appear with the passage of time, ${ }^{40}$ the second approach is equally troublesome because it offers little reassurance to the settlor that her vision will be followed, scant guidance to the trustee on how best to accommodate the different interests, and few guideposts to the beneficiaries on whether the trustee is acting in accordance with the trust that the settlor has reposed in her. In fact, all this approach offers is a relationship, situated in the context of standards for fiduciary conduct generally. ${ }^{41}$ How can a trustee be trusted to deal with these problems? One answer lies in fiduciary law.

37. Halbach, supra note 36, at 1426-27; see also Peter B. Tiernan, A Trustee's Duties and Responsibilities Under Discretionary Invasion Provisions, FLA. B. J., Oct. 2005, at 50 (describing standards of discretion that appear in trusts).

38. Cooter \& Freedman, supra note 3, at 1048-49. Actually, this dilemma of delegation is inherent in any fiduciary relationship, where one party holds power over another, see Frankel, supra note 10 , at $809-10$, but is further complicated by the tripartite nature of the trust relationship.

39. See infra notes 74-78 and accompanying text.

40. See Cooter \& Freedman, supra note 3, at 1048-49. Although default rules often help clarify obligations where an instrument is silent, see, e.g., Adam J. Hirsch, Default Rules in Inheritance Law: A Problem in Search of Its Context, 73 Fordham L. Rev. 1031, 1101 (2004) [hereinafter Hirsch, Default Rules], whether these default rules are satisfactory has been another subject of avid debate. See Cooper, supra note 2, at 1172 n. 32; Adam J. Hirsch, Text and Time: A Theory of Testamentary Obsolescence, 86 WASH. U. L. REV. 609, 627-28 (2009); Hirsch, Default Rules, supra, at 1039; Melanie B. Leslie, Enforcing Family Promises: Reliance, Reciprocity, and Relational Contract, 77 N.C. L. REv. 551, 586-609 (1999) [hereinafter Leslie, Family Promises]; see also Leslie, supra note 6, at 70 (arguing that characterizing trustees' fiduciary duties as "pure 'default rules' ... blinds academics and courts to the need to develop a coherent theory about the extent to which fiduciary duties can be modified").

41. See Pruett, supra note 31, at 341 ("One of the most difficult tasks trustees face is how to exercise broad (and generic) discretion in the administration of trusts, whether the trust is fully discretionary, with no standards whatsoever, or discretionary subject to an ascertainable standard."); Robert H. Sitkoff, Trust Law as Fiduciary Governance Plus Asset Partitioning, in THE WORLDS OF THE TRUST 428, 430-31 (Lionel Smith ed., 2013) ("[Spelling] out with specificity what the trustee should do in all possible future circumstances [is] an impossible task given transaction costs and the settlor's lack of clairvoyance. Instead, trust law provides the trustee with expansive default powers 


\section{B. The Trustee's Roles and Duties}

Repeatedly characterized as the quintessential fiduciary, ${ }^{42}$ the trustee wields tremendous power based on her legal ownership and control of the trust property, her superior access to information, and, in many cases, the experience, expertise, and even status that caused her to be appointed in the first place. ${ }^{43}$ Accordingly, her duties are significant, commensurate with her position and designed to combat any potential opportunism or laziness. ${ }^{44}$

The trustee has a duty of loyalty that obligates her to put the requirements of the entrustor and beneficiaries before her own. ${ }^{45}$ The duty of loyalty prohibits the trustee from engaging in any transactions that are self-interested or conflicted, even if such actions might confer an economic benefit on the trust. ${ }^{46}$ If a trustee breaches her duty of loyalty to the beneficiaries by engaging in a self-interested or potentially conflicted transaction, any profits that the trustee earns belong to the beneficiaries with "no further inquiry." 47 This strong prophylactic rule is

of administration, the trustee's exercise of which is subject to review ex post for compliance with the open-ended fiduciary duties of loyalty and prudence.").

42. Frankel, supra note 10, at 804-05; Austin W. Scott, The Fiduciary Principle, 37 CAL. L. REV. 539, 540 (1949); see also DeMott, supra note 27, at 912 (characterizing trustee as "a powerful prototype" of the fiduciary); Sitkoff, supra note 3, at 641 ("The . . office of the trustee serves as the organizing hub for the various relations that aggregate into the trust."); Edward D. Spurgeon \& Mary Jane Ciccarello, The Lawyer in Other Fiduciary Roles: Policy and Ethical Considerations, 62 FORDHAM L. REV. 1357, 1361 (1994) ("Fiduciary relations typically include those of trustee/beneficiary, guardian/ward, conservator/conservatee, principal/agent, attorney/client, partner/partner, executor/legatee.").

43. Frankel, supra note 10, at 809-10, 813-14.

44. See Cooter \& Freedman, supra note 3, at 1048-57.

45. SCOTT ON TRUSTS, supra note $3, \S 17.2$; Langbein, Questioning, supra note 10, at 931; see also Frankel, supra note 10, at 823-24 (speaking to the fiduciary acting in the best interests of the entrustor); Cooper, supra note 2, at 1167 (stating that the trustee is "held to the highest fiduciary duty of loyalty" for the "sole interest of the trust beneficiaries"). The most famous description of the fiduciary duty of loyalty comes from Justice Cardozo's decision in Meinhard v. Salmon, 164 N.E. 545,546 (N.Y. 1928) ("Many forms of conduct permissible in a workaday world for those acting at arm's length, are forbidden to those bound by fiduciary ties. A trustee is held to something stricter than the morals of the market place. Not honesty alone, but the punctilio of an honor the most sensitive, is then the standard of behavior."); see also In re Estate of Rothko, 379 N.Y.S.2d 923, 932-52, 965-78 (Sur. Ct. 1975) (relying on Meinhard to find fiduciaries to have breached duty of loyalty in connection with administering estate of Mark Rothko), modified, 392 N.Y.S.2d 870 (N.Y. App. Div. 1977), aff'd, 372 N.E.2d 291 (N.Y. 1977).

46. Langbein, Contractarian Basis, supra note 2, at 655-56. The only defenses a trustee may raise are that a court approved the transaction in advance or the other parties to the trust waived the conflict; otherwise, there is "no further inquiry" and any profits the trustee makes belong to the trust. See Alexander, supra note 10, at 776.

47. Cooter \& Freedman, supra note 3, at 1054-56; Leslie, supra note 6, at 112-13. Because the beneficiaries' interests are distinct from the trustee's, the trustee must segregate and maintain trust assets separately. SCOTT ON TRUSTS, supra note $3, \S 17.11$. 
designed to counter-balance the potential for misappropriation of opportunities that the trustee's legal ownership of the property and superior information about it affords her. ${ }^{48}$

The trustee also has a broad and overarching duty of care that can be further broken down into responsibilities for investments and distributions. ${ }^{49}$ With respect to investments, the duty of care once simply required the trustee to custody the assets and keep them safe. ${ }^{50}$ As trust property evolved from ancestral land to liquid assets, like stocks and bonds, trust investment law experienced a corresponding and seismic transformation too. ${ }^{51}$ Modern trust law now affirmatively requires the trustee to manage investments to achieve a favorable overall return, to understand a trust's (and its beneficiaries') purposes and risk tolerance, to diversify holdings, and to delegate investment responsibility if the trustee lacks the requisite expertise. ${ }^{52}$ In fact, trustees who delegate their investment duties to advisors, under modern rules, can escape liability for mismanagement, so long as the advisor was properly selected, directed, and monitored. ${ }^{53}$ To be deemed prudent, the trustee's investment strategy must account for the competing needs of life and remainder beneficiaries. ${ }^{54}$ In tandem with these expectations, many jurisdictions have adopted statutes that give trustees flexibility to deal

48. Langbein, Contractarian Basis, supra note 2, at 655-56. at 656 .

49. See SCOTT ON TRUSTS, supra note 3, § 17.6; Langbein, Contractarian Basis, supra note 2,

50. See Langbein, Contractarian Basis, supra note 2, at 640.

51. See Stewart E. Sterk, Rethinking Trust Law Reform: How Prudent Is Modern Prudent Investor Doctrine?, 95 CORNELL L. REV. 851, 856-67 (2010) (describing evolution of modern investment rules).

52. Sterk, supra note 51, at 853-54; see generally In re Estate of Janes, 681 N.E.2d 332, 33639 (N.Y. 1997) (describing standards of the "prudent person rule of investment"); John H. Langbein, The Uniform Prudent Investor Act and the Future of Trust Investing, 81 IowA L. REV. 641, 645-46 (1996) (citing and discussing modern rules under the Uniform Prudent Investor Act and the Restatement (Third) of Trusts)).

53. ScOtT On Trusts, supra note $3, \S 17.3$; UnIF. PRUdent InV. ACT $\S 9$ (1994); UnIF. TRUST CODE $\S 807$ (amended 2010).

54. See Sitkoff, supra note 3, at 650-54; see also Carter v. Carter, 965 N.E.2d 1146, 1155-56 (Ill. App. Ct. 2012), appeal denied, 968 N.E.2d 1064 (Ill. 2012) (rejecting daughter's claim that mother-trustee breached her fiduciary duties of impartiality and prudence by knowingly engaging in an investment strategy that prioritized income interest over remainder interests by investing solely in municipal bonds); Matter of Estate of Butterfield, 341 N.W.2d 453, 459 (Mich. 1983) ("Another duty of trustees is to be impartial in their investment policies. Neither income beneficiaries nor remaindermen may be favored. All trust beneficiaries must be dealt with impartially unless a different intent is clearly expressed in the trust document."); Cooper v. Cooper, 913 P.2d 393, 398 (Wash. Ct. App. 1996) (affirming trial court's finding that father-trustee's investment strategy, which weighed in favor of income over trust appreciation, was breach of duty to act as prudent investor). 
with different types of property, often far more varied and volatile than the property trusts historically owned and managed. ${ }^{55}$

The duty of care also requires the trustee to distribute assets appropriately. ${ }^{56}$ Although the trust relationship sometimes is characterized as triangular, based on the three categories of interested parties (settlor, trustee, and beneficiaries), in reality the relationship is more faceted. For example, "the same person may play more than one of the three roles" 57 and the roles may have internal divisions. Beneficiaries who receive lifetime distributions have potentially adverse interests to the remaindermen because the more property that passes to one, the less that remains for the other. ${ }^{58}$ Even collateral beneficiaries - those who are on the same horizontal level, such as siblings-compete for distributions. ${ }^{59}$ The trustee has a duty to treat the beneficiaries impartially and accommodate their divergent interests when deciding whether to make a distribution. ${ }^{60}$

Other duties, sometimes mentioned separately and sometimes as part of the more general duties of loyalty and care, can be characterized as process and enforcement-based. For example, the trustee must file periodic accounts and keep beneficiaries informed. ${ }^{61}$ Donative trusts are often preferred over other gifting vehicles for the privacy advantages they offer, ${ }^{62}$ and it has not been uncommon for settlors and trustees to

55. See Sterk, supra note 51, at 853-54.

56. SCOTT ON TRUSTS, supra note $3, \S \S 17.14-15$.

57. Hansmann \& Mattei, supra note 16, at 438; see also, e.g., In re Trust No. T-1 of Trimble, 826 N.W.2d 474, 488 (Iowa 2013) (involving revocable trust where settlor served as co-trustee and beneficiary served as co-trustee and executor of settlor's estate).

58. Sitkoff, supra note 3, at 650-52; see, e.g., In re G.B. Van Dusen Marital Trust, 834 N.W.2d 514 (Minn. Ct. App. 2013) (describing life beneficiary and remainder beneficiaries' conflicting interests).

59. Richard M. Horwood \& Jeffrey A. Zaluda, A Trustee's Balancing Act: Income and Remainder Beneficiaries' Rights, 30 EsT. PLAN. 12, 14 (2003).

60. UNIF. TRUST CODE $\S 803$ (amended 2010); see also RESTATEMENT (SECOND) OF TRUSTS $\S \S 183,232$ (1959) (stating that a trustee is "under a duty to deal impartially" with trust beneficiaries and that, "if a trust is created for beneficiaries in succession," a trustee is under a duty to act "with due regard" to the interests of those successive beneficiaries); Ronald R. Volkmer, New Fiduciary Decisions: Issues Related to Alleged Breaches of Fiduciary Duties By Trustees, 39 EsT. PLAN. 44, 46 (2012) (citing and discussing cases).

61. SCOTT ON TRUSTS, supra note 3, §§ 17.4-5; Langbein, Mandatory Rules, supra note 35, at 1125-26; see also Leib et al., supra note 18, at 738 (discussing accurate bookkeeping responsibilities of the fiduciary).

62. See Frances H. Foster, Privacy and the Elusive Quest for Uniformity in the Law of Trusts, 38 ARIZ. ST. L.J. 713, 725-27 (2006) [hereinafter Foster, Elusive Quest]; Frances H. Foster, Trust Privacy, 93 CORNELl L. REV. 555, 559-65 (2008). 
want to minimize disclosure obligations to maintain this privacy. ${ }^{63}$ Some reasons to do so might include a concern that beneficiaries will become lackadaisical, greedy, or meddlesome if they are given too much information about the trust. ${ }^{64}$ Accordingly, trustees have traditionally resisted disclosing what they are doing unless required to do so by the trust instrument or by law. ${ }^{65}$ In the modern era, both the Uniform Trust Code and state legislatures have required trustees to provide "qualified" beneficiaries with disclosure about trust activity. ${ }^{66}$ Professor Thomas Gallanis and others have argued convincingly that these disclosure requirements should be mandatory because they help monitor trustee misconduct and especially trustees' opportunism. ${ }^{67}$ Some states have agreed, prohibiting settlors from waiving the requirement in their trust instruments, and others have not. ${ }^{68}$

In thinking about fiduciary duties, it is worth noting how recent years have seen increased use of quasi-fiduciaries, known as "trust protectors" or "trust directors," and a corresponding debate about their status. ${ }^{69}$ Several jurisdictions permit a settlor to "designate a surrogate to receive

63. See Foster, Elusive Quest, supra note 62, at 750; T.P. Gallanis, The Trustee's Duty to Inform, 85 N.C. L. REV. 1595, 1603 (2007); Edward C. Halbach, Jr., Uniform Acts, Restatements, and Trends in American Trust Law at Century's End, 88 CAL. L. REV. 1877, 1914-15 (2000).

64. Foster, Elusive Quest, supra note 62, at 763-64.

65. But see Gallanis, supra note 63, at 1610-17 (arguing that disclosure requirements are consistent with trust history and economic theory).

66. See UNIF. TRUSt CODE $\S 813$ (amended 2010).

67. Gallanis, supra note 63, at 1620-23; Langbein, Mandatory Rules, supra note 35, at 112526; see also Estate of Alden v. Dee, 35 A.3d 950, 956 (Vt. 2011) ("Disclosure by a trustee is fundamental to sound trust administration and the beneficiaries' ability to monitor the trustees' performance of their duties.") (citing RESTATEMENT (THIRD) OF TRUSTS $\S 82 \mathrm{cmt}$. d (2007)).

68. See, e.g., In re Trust No. T-1 of Trimble, 826 N.W.2d 474, 485-89 (Iowa 2013) (describing disclosure rules and finding no duty to account to remainder beneficiaries for period during which settlor was alive and trust was revocable); Johnson v. Johnson, 967 A.2d 274, 283 (Md. Ct. Spec. App. 2009) (requiring trustee, who was also present income beneficiary, to account to step-son, who had a vested but contingent remainder interest, even though trust agreement excused such accounting), vacated, 32 A.3d 1072 (Md. 2011); see also Foster, Elusive Quest, supra note 62, at 742-51 (describing various state and uniform statutes). See generally Philip J. Ruce, The Trustee and the Remainderman: The Trustee's Duty to Inform, 46 REAL PROP. TR. \& EsT. L.J. 173 (2011) (describing history of disclosure requirements and UTC and Restatement reforms).

69. See SCOTT ON TRUSTS, supra note 3, at $\S 16.7$; Gallanis, supra note 63, at 1624-26; see also Gregory S. Alexander, Trust Protectors: Who Will Watch the Watchmen?, 27 CARDOZO L. REV. 2807, 2807-11 (2006) (discussing the utility of trust protectors); Richard C. Ausness, The Role of Trust Protectors in American Trust Law, 45 Real Prop. TR. \& EST. L.J. 319, 338-40 (2010) (same); Alexander A. Bove, Jr., The Case Against the Trust Protector, 37 ACTEC L.J. 77, 81-91 (2011) (same); Leslie, supra note 6, at 83 (same); Philip J. Ruce, The Trustee and the Trust Protector: A Question of Fiduciary Power. Should a Trust Protector Be Held to a Fiduciary Standard?, 59 DraKe L. REV. 67, 68 \& n.1 (2010); Stewart E. Sterk, Trust Protectors, Agency Costs, and Fiduciary Duty, 27 CARDOZO L. ReV. 2761, 2763 (2006) (same). 
and request information in lieu of the beneficiaries," although they fail to address "crucial questions" such as "whether the surrogate owes fiduciary duties to the beneficiaries, what standard of care governs the surrogate's actions or failures to act, and whether the surrogate has standing to sue the trustee for fiduciary breach.," assigned to these designees might include making distributions, ${ }^{71}$ removing and replacing fiduciaries, ${ }^{72}$ updating the trust agreement for changes in the law, ${ }^{73}$ or other creative trust oversight functions.

\section{Responding to the Challenge: Existing Legal Taxonomies and Analogies}

Although the duties of a trustee might seem fairly straightforward and well established, they have led to an ongoing scholarly debate over whose interests a trustee should prioritize,${ }^{74}$ and a continuing stream of litigation over whether the trustee is balancing the competing interests appropriately in light of her fiduciary duties, the trust instrument, and changes over time. ${ }^{75}$ On the one hand, "[a] central feature of fiduciary relations is that the fiduciary serves as a substitute for the entrustor," 76 and the settlor's intent as to how a trust operates is binding. ${ }^{77}$ On the other hand, a private trust is meaningless without beneficiaries, and the trustee's primary responsibilities are to act on their behalf and for their benefit. ${ }^{78}$ In considering how to balance the rival interests of settlor and

70. Gallanis, supra note 63, at 1625.

71. See, e.g., Shelton v. Tamposi, 62 A.3d 741, 746 (N.H. 2013) (trust "directors" for investments).

72. Sterk, supra note 69 , at 2768-69.

73. Id. at 2766-69.

74. See Cooper, supra note 2, at 1172 ("While the case law repeatedly reaffirms the traditional primacy of a settlor's intent, the literature increasingly emphasizes the needs of trust beneficiaries and the dictates of modern investment theory."); Gallanis, supra note 2, at 218-34 (describing shift from prioritizing settlor's intent on issues of trust administration to prioritizing beneficiary needs); Horton, supra note 14, at 64 n.22 (describing the "vigorous debate" over what has been called the "benefit-the-beneficiaries" rule).

75. See O’Riley v. U.S. Bank, N.A., 412 S.W.3d 400, 405 (Mo. Ct. App. 2013), transfer denied (Oct. 29, 2013); In re Estate of Hedke, 775 N.W.2d 13, 39 (Neb. 2009); In re Heller, 849 N.E.2d 262, 266 (N.Y. 2006); Howard v. Howard, 156 P.3d 89, 89-91 (Or. Ct. App. 2007); Estate of Alden v. Dee, 35 A.3d 950, 957 (Vt. 2011).

76. Frankel, supra note 10 , at 808 .

77. See Kelly, supra note 28, at 1134; Sitkoff, supra note 3, at 638.

78. AMY MORRIS Hess et AL., THE LAW OF TruStS AND TRUSTEES $\S 1$ (3d ed. 2007); Cooper, supra note 2, at 1166-67; DeMott, supra note 27, at 901. 
beneficiaries, scholars have proposed different "legal taxonomies"79 for the private donative trust. The traditional view, long-held but still pervasive, sees trusts as property conveyances and fiduciary law as the mechanism for regulating the parties' duties and obligations with respect to that property. ${ }^{80}$ Those who view trust law as property-based generally prioritize the beneficiaries' interests in maintaining and growing the property over the settlor's "dead hand" interests. ${ }^{81}$

Another theory, put forth most famously in modern scholarship by Professor John Langbein, is that trusts are third-party beneficiary contracts between the settlor and trustee. ${ }^{82}$ Those who accept the contractarian approach believe that the settlor can define the trust's parameters, regardless of the impact on the trust beneficiaries, except for certain mandatory rules the abrogation of which would "authorize the trustee to loot the trust." ${ }^{\prime \prime 3}$ This paradigm acknowledges the temporal nature of the trust relationship by comparing a trust to a long-term "relational contract" with its many managerial challenges. ${ }^{84}$ On the other hand, this analogy has been criticized for overlooking some of the most fundamental justifications for freedom of contract and neglecting the

79. See Hirsch, supra note 13, at 2181 ("[L] egal taxonomy guides lawmakers to scout in given directions for relevant symmetries and analogies. It serves, in other words, as a sort of compass, which - depending on how well it is calibrated - can send lawmakers wandering down blind alleys or lead them straight to the heart of things."); see also Sitkoff, supra note 3, at 627-28 (describing "[e]arly participants in this debate, which has been ongoing for over 100 years" to include "Frederic Maitland (who took a contractarian perspective), Austin Scott (who took a proprietary perspective), and Harlan Fiske Stone (who took a contractarian perspective)").

80. See supra note 13; see also Alexander, supra note 10, at 768; Gallanis, supra note 63, at 1621 ("The modern law of fiduciary administration enforces a proprietarian boundary on the settlor's contractarian power. The settler of an irrevocable trust is given significant room to control the trustee's actions but cannot dispense with the core responsibility of the trustee to administer the trust in the interests of the beneficiaries.").

81. Gallanis, supra note 2, at 234-36.

82. Langbein, Contractarian Basis, supra note 2, at 652; Cooper, supra note 2, at 1182; see also Hirsch, supra note 13, at 2183 (arguing that "associating the law of gratuities with the law of contracts" pays "conceptual dividends").

83. Langbein, Mandatory Rules, supra note 35, at 1106.

84. Langbein, Contractarian Basis, supra note 2, at 653-54 \& n.151. But see Leslie, supra note 6, at 78-79 ("The corporate 'contract' is relational, not contemplating a one-shot performance by each party, but a continuing relationship that may stretch years into the future. Parties cannot draft agreements that accurately anticipate and resolve all future conflicts" (footnotes omitted)). For a definition of relational contracts, see Charles J. Goetz \& Robert E. Scott, Principles of Relational Contracts, 67 VA. L. REV. 1089, 1091 (1981) ("A contract is relational to the extent that the parties are incapable of reducing important terms of the arrangement to well-defined obligations . . . because of inability to identify uncertain future conditions or because of inability to characterize complex adaptations adequately even when the contingencies themselves can be identified in advance."). For sources discussing relational contracts in the inheritance context, see Leslie, Family Promises, supra note 40 , at $554 \&$ n. 3 . 
moral elements of fiduciary law. ${ }^{85}$ As authors of a book about trust and mistrust in business relationships have stated so vividly, contracts "are not good foundations for relationship development" because they are "as much something to hide behind" as they are vehicles for confronting difficult problems. ${ }^{86}$

Acknowledging the "potential for considerable tension" between the trustee's obligations to the settlor, as the "primary principal," and to the beneficiaries, who have a "residual claim" to the trust property, Professor Robert Sitkoff has offered an organizational theory of trust law that seeks to "minimize the [transaction] costs . . . but only to the extent that doing so is consistent with the ex ante instructions of the settlor." organizational model has the advantage of recognizing the trustee's contractual obligations to the settlor and fiduciary obligations to the beneficiaries, ${ }^{88}$ but also the limits of that model, both regarding internal governance-especially where tensions arise among different classes of beneficiaries - and relationships with external players, like creditors. ${ }^{89}$ This model has been criticized, though, for prioritizing efficiency and reduced transaction costs, at least in practice if not in intent, and downplaying the many idiosyncratic and expressive reasons for which people establish trusts. ${ }^{90}$

In response to the foregoing theories, which see "wills and trusts law as analogous to other fields that regulate the use, transfer, or investment of assets," Professor David Horton argues that testation is fundamentally

85. See Scott FitzGibbon, Fiduciary Relationships Are Not Contracts, 82 MARQ. L. ReV. 303, 305 (1999) (explaining how "contractualist" ideas differ from fiduciary duties in that the latter "facilitate the doing of justice, ... promote virtue, and ... enhance freedom in a distinctive way"); Hirsch, supra note 13, at 2193-95, 2207-10 (describing doctrinal areas where contracts and trusts have similar theoretical rationales but different approaches and results); Horton, supra note 14, at 74-75 (describing differences between social welfare maximization rationale which supports freedom of contract and donative intent rationale which supports freedom of testation).

86. WARD \& SMITH, supra note 19, at 13-14.

87. Sitkoff, supra note 3 , at 640,648 .

88. Id. at 624 ("In the prototypical donative trust, the settlor ('S') in effect contracts with the trustee (' $\mathrm{T}$ ') to manage a portfolio of assets in the best interests of the beneficiaries ('B1' and 'B2,' collectively the 'Bs'), subject to the ex ante restraints imposed by the settlor." (emphasis added)). But see Tritt, supra note 3, at 2584-85 (criticizing "agency costs" theory, in part, because it disregards "whether trustees remain agents of settlors who create the trusts (and gratuitously transfer property into trust), the trust beneficiaries (who equitably enjoy the benefits of the gifts), or the trust itself" and ignores "the actions of a beneficiary that might create agency costs to other beneficiaries (for example, a current beneficiary affecting a co-beneficiary, remainder beneficiary, or contingent beneficiary)").

89. Sitkoff, supra note 3 , at $650-57,672-76$.

90. Tritt, supra note 3, at 2601-16; Horton, supra note 14, at 76-77. 
different because it is "profoundly expressive." 91 After explaining the many ways that property owners use their wills and trusts to communicate their preferences, Horton examines how this recognition impacts trust doctrine. ${ }^{92}$ Most pertinently, he argues that when a court is evaluating whether a direction in a testamentary instrument should be honored or modified - in other words, whether such direction by the settlor should be respected or rejected as not beneficial to the trust's beneficiaries - the court "should factor testamentary self-expression into the equation somewhere." 93 Thus, the "testation as speech" paradigm adds yet another competing interest into the consideration: the speech itself.

While these ideas about how to think of trusts are insightful, they have not ended the conversation about how to prioritize interests nor increased trust among parties to the trust relationship. In fact, in seeking to create a totalizing paradigm, theorists have highlighted just how much of a legal patchwork trust law is. Moreover, that legal patchwork has affected how people in the world function within trust relationships. Trustees continue to struggle with investment and distribution directives, estate planners continue to struggle with drafting to accomplish settlor and beneficiary wishes and needs, settlors continue to struggle with selecting trustees and guiding their conduct, and beneficiaries still express dismay with trustee decision-making. Also, current scholarship, for the most part, focuses on management strategies, and liability for mismanagement, and downplays the question of how and when a trustee should make distributions. ${ }^{94}$

In a recent piece entitled $A$ Fiduciary Theory of Judging, the authors propose a "judge-as-fiduciary" framework that, they contend, provides a "normative benchmark" for how judges should conduct themselves. ${ }^{95}$ Accepting that fiduciary law is a "centuries-old rubric that governs trusting relationships,"

\footnotetext{
91. Horton, supra note 14 , at 89.

92. Id. at $89-111$.

93. Id. at 108 .

94. See Langbein, Contractarian Basis, supra note 2, at 650-51 (describing the trust as a voluntary deal between settlor and trustee consisting of numerous default rules and stating that the trustee "is normally indifferent to the distributive provisions"); Sitkoff, supra note 3, at 661-62 (describing in a single paragraph how decisions regarding trust modification require consideration of settlor intent regarding distributions). But see Horton, supra note 14, at 66 (recognizing that "an owner's distributional choices can be highly (albeit implicitly) expressive").

95. Leib et al., supra note 18 , at 703 .

96. Id.
} 
of today's most controversial debates" ${ }^{97}$ about the judiciary. ${ }^{98} A$ Fiduciary Theory of Judging provides historical and functional reasons why judges should be considered fiduciaries, including that they are entrusted to exercise discretion on behalf of people who have far less power than they themselves wield, ${ }^{99}$ and that they must do so in a way that balances independence and constraint. ${ }^{100}$ Most importantly for the purposes of this Article, the authors show that the two theoretical constructs are useful touchstones for each other because each helps to illuminate and even reframe some of the controversial questions about the other. Rather than thinking about the trustee as an agent of the settlor or, alternatively, as an agent of the beneficiaries, comparing judges and trustees involves seeing the trustee as a decision-maker whose purpose is to find and expose a common ground that serves all of the parties' interests in light of the trust's challenges of fractionalized ownership and temporal uncertainty. ${ }^{101}$ This framework can therefore have a powerful effect on how settlors choose trustees and guide their conduct and how trustees meet their investment and distribution obligations to satisfy settlor goals and beneficiary expectations. The next Part describes the power of this analogy.

\section{ENVISIONING TRUSTEES AS JUDGES}

One of the reasons why the legal interactions among settlor, trustee, and beneficiaries stimulate so much discussion is that current law envisions these parties in an adversarial relationship, which is hardly surprising given the multiple and diverse interests involved in the typical private donative trust. ${ }^{102}$ The settlor has a vision for how her property will be held, invested, and distributed; the trustee has obligations imposed both by the law and the trust instrument; and the beneficiaries have needs that sometimes conflict with those of other beneficiaries and

97. Id.

98. See, e.g., id. at 731-36 (observing the many ways that the fiduciary duty of loyalty already applies to judges and arguing that loyalty also supports stricter recusal standards); id. at 736-38 (observing the many ways the fiduciary duty of care already applies to judges and arguing that care supports a more cautious use of law clerks); id. at 738-52 (observing how the fiduciary duties of candor, disclosure, and accounting apply to judges and arguing that these duties also support an obligation of "deliberative engagement").

99. Id. at 714-17.

100. Id. at 705 .

101. Frankel, supra note 10, at 831-32.

102. See, e.g., infra note 249 (describing cases). 
possibly with what the settlor had originally intended. ${ }^{103}$ Underlying these interests is the fact that trusts are intended to be dynamic vehicles that facilitate property management when the original owner is no longer around to respond to new events that may change the property and the beneficiaries. In the owner's stead, the trustee must adapt and react. If a trust relationship is functional, it should proceed intact and supervised by the parties; if it is dysfunctional, it may end up in court or at least in turmoil. ${ }^{104}$

Consider, for example, a recent case, In re G.B. Van Dusen Marital Trust, that is simply one among many disputes about trusts, but is useful because it illustrates beautifully both the challenges posed by gifts over time and the problems that can arise when a beneficiary loses confidence - or trust - in the trust's decision-maker. ${ }^{105}$ The Van Dusen settlor and his wife, Virginia, married in 1978, both having been married

103. See supra notes $4-9$ and accompanying text.

104. See Leslie, supra note 6, at 104 (“American courts 'have invariably played an active and indispensable role' in monitoring long-term relational contracts; the American tolerance for contractual freedom has typically been counterbalanced by judicial activism in monitoring for opportunism." (citation omitted)); Leib et al., supra note 18, at 729 ("As a general matter, we tend to see large-scale compliance with private fiduciary obligations because the norms are so deeply rooted and function mostly extrajudicially."); Ethan J. Leib, Friends as Fiduciaries, 86 WASH. U. L. REV. $665,685-86$ (2009) (same).

105. In re the G.B. Van Dusen Marital Trust, 834 N.W.2d 514 (Minn. Ct. App. 2013). While the case provides a useful illustration, it is simply one of many examples of trust administration disputes that drained trust assets and could have benefited from enhanced procedures of the type discussed below. For other examples, see Rollins v. Rollins, 755 S.E.2d 727, 730 (Ga. 2014) (discussed infra at notes 251-59 and accompanying text); Smith v. SunTrust Bank, 754 S.E.2d 117, 121-22 (Ga. Ct. App. 2014) (absence of accountings and single letter from corporate trustee to beneficiaries announcing its future distributions led, in part, to beneficiaries objecting when trustees moved to terminate trusts as uneconomical); Marsman v. Nasca, 573 N.E.2d 1025, 1031-33 (Mass. App. Ct. 1991) (finding lawyer-trustee to have breached a duty of "inquiry and distribution" that ultimately resulted in beneficiary losing his home); Wilbourn v. Wilbourn, 106 So. 3d 360 (Miss. Ct. App. 2012), reh'g denied (Sept. 25, 2012), cert. denied, 105 So. 3d 326 (Miss. 2013) (granting removal petition because, among other things, trustee secretly recorded mother/co-trustee); O'Riley v. U.S. Bank, N.A., 412 S.W.3d 400, 410-12 (Mo. Ct. App. 2013), transfer denied (Oct. 29, 2013) (describing trustee's communications with beneficiaries, finding distribution decisions reasonable, and denying damages claim for failure to provide account statements; describing how beneficiaries felt ignored); Miller v. Bank of Am., 326 P.3d 20, 26 (N.M. Ct. App. 2013), cert. granted, 326 P.3d 1112 (N.M. May 1, 2014) ("Beneficiaries received limited information about the [Trustee's] actions, had many unanswered questions about the management of the Trusts, and the [Trustee] actually misrepresented the value of the Building that was carried on its books."); Cooper v. Cooper, 913 P.2d 393, 395 (Wash. Ct. App. 1996), review denied by 928 P.2d 414 (Wash. Nov. 13, 1996) (describing substantial fees paid by trust where "[trustee] filed his wife's will and started a probate. But he took no further steps to conclude the probate until [beneficiary] filed this action. [Trustee] did not keep a separate estate account and continued to manage all of the former community property as his own.”). 
before and with adult children from their prior unions. ${ }^{106}$ The revocable trust agreement, which the settlor created in 1981, provided for income as the settlor requested during his life and, on his death, for three separate trusts: a marital trust (the Marital Trust); a trust funded with the settlor's remaining exemption from generation-skipping transfer tax (the GST Trust); and a family trust funded with any assets remaining in the marital trust after the death of the settlor's wife (the Family Trust). ${ }^{107}$ Both the GST and Family Trusts benefited the settlor's children and more remote descendants. ${ }^{108}$ The Marital Trust, though, benefited Virginia, providing her with all income and principal as the trustee deemed "advisable to provide for her health, education, support, maintenance and care." $" 109$ In determining whether to make a principal distribution to Virginia, the trustee was directed to "use principal liberally" to maintain Virginia "insofar as possible the standard of living to which she was accustomed during" the settlor's lifetime. ${ }^{110}$ The trust agreement further provided that the trustee was under no obligation "to consider other assets or income available" to Virginia and specifically acknowledged that the Family Trust might never be funded if Virginia consumed all of the assets of the Marital Trust. ${ }^{111}$ Finally, Virginia was given the power to "compel conversion" of any unproductive property to make it productive. ${ }^{112}$ Although the trial court stated that the language of the agreement was "certainly not a model of clarity," it is hard to imagine a trust agreement that is any clearer in expressing the settlor's intent to benefit a surviving spouse over remainder beneficiaries than the Van Dusen agreement.

The settlor died in 1999 and for approximately ten years the surviving spouse, Virginia, received income from the trust and varying amounts of principal, though far less than she had lived on when the settlor was alive. ${ }^{113}$ During this period, the trustee and Virginia

\footnotetext{
106. In re G.B. Van Dusen Marital Trust, 834 N.W.2d at 517.

107. Id.

108. Id.

109. The entire provision is quoted in the trial court order, which can be found at In re Van Dusen Marital Trust, No. 27TRCV1063, 2012 WL 217240, at *2 (Minn. Dist. Ct. Jan. 20, 2012), rev'd, 834 N.W.2d 514 (Minn. Ct. App. 2013) [hereinafter Van Dusen Trial Court].

110. In re G.B. Van Dusen Marital Trust, 834 N.W.2d at 517-18.

111. Id. at 518 .

112. Id

113. Id. ("Between 2000 and 2011, Virginia received an average of approximately $\$ 93,000$ per year in income distributions from the Marital Trust. During the same period, Virginia received no principal distributions in some years and varying amounts of principal distributions in other years:
} 
"appeared to enjoy a good relationship," until Virginia learned that the trustee had failed to make a sizable principal distribution some years earlier; ${ }^{114}$ the source of Virginia's knowledge about the error is not discussed in either the lower court or appellate opinion, although both opinions insinuate that the trustee's mode of communicating the mistake was neither forthright nor conciliatory. ${ }^{115}$ Accordingly, a decade after the trust was funded, Virginia started requesting that the trustee make a series of larger principal distributions to help her pay various living expenses and attorney fees. The then institutional trustee ${ }^{116}$ sought a meeting to discuss whether Virginia's financial situation had changed to justify the increased distributions and thereafter denied Virginia's entire request. ${ }^{117}$ Again, it is not clear in what form the denial came and whether the trustee provided any explanation to Virginia at that time.

Based on a valid concern that granting Virginia's requests might eviscerate the remainder beneficiaries' interests and thus violate its duty of impartiality, the trustee sought guidance from the probate court, ${ }^{118}$ which approved the trustee's exercise of discretion in all respects. ${ }^{119}$ The appellate court reversed. ${ }^{120}$ Recognizing the trustee's duties to the remainder beneficiaries, the appellate court nevertheless found that the trust agreement required the trustee to distribute principal "liberally" to

$\$ 6,507$ in 2002 ; $\$ 6,467$ in $2005 ; \$ 16,528$ in 2006 ; $\$ 17,811$ in 2007 ; $\$ 60,019$ in 2008 ; $\$ 49,204$ in 2009; $\$ 23,404$ in 2010; and $\$ 73,771$ in 2011.”).

114. Id.; see also Van Dusen Trial Court, supra note 109, at *9 ("Jean Morse, one of Virginia Van Dusen's daughters-in-law, eventually discovered that the $\$ 49,000$ distribution had not been made.").

115. Van Dusen Trial Court, supra note 109, at *9 ("Mrs. Van Dusen repeatedly emphasizes the fact that the Trustee never informed her about the error, and for this (and the error itself), the Trustee should be removed for breach of its duty of loyalty."); see also id. at *8 ("Virginia Van Dusen argues that the Trustee violated its duty of loyalty by failing to make a $\$ 49,247.42$ principal distribution, requested by Mrs. Van Dusen in 2001, and subsequently failing to inform Mrs. Van Dusen that it had not been made. The Trustee argues that this was potentially due to an error or oversight by the Trustee, but that such an error has since been corrected, as the Trustee distributed the funds in 2011."); id. at *10 ("The Trustee does have a duty to communicate with Mrs. Van Dusen and keep her apprised of situations involving the Trust and their own conduct. However, their failure in this instance is tempered by the fact that Mrs. Van Dusen was clearly aware of the error ....").

116. Originally an individual trustee served with the corporate trustee, but the individual resigned without appointing a successor and, under the trust agreement, the corporate trustee thereafter served alone. There were some allegations that the resignation was prompted by the corporate trustee. "Wells Fargo, through Lowry Hill, has administered the Trust as the sole trustee since 2001, after the resignation of the former co-trustee...." Van Dusen Trial Court, supra note 109 , at $* 2$.

117. In re G.B. Van Dusen Marital Trust, 834 N.W.2d at 518-19.

118. Id. at 519 .

119. Van Dusen Trial Court, supra note 109 , at *15.

120. In re G.B. Van Dusen Marital Trust, 834 N.W.2d at 521. 
maintain Virginia's style of living and allowed Virginia to compel the trustee to convert "unproductive" (which the court interpreted to be nonincome producing) property into "productive" (or income producing) property, even if these actions resulted in the settlor's adult children never receiving property from the trust. ${ }^{121}$ That Virginia had foregone certain choices during the prior ten years was irrelevant to future distributions because the trust agreement's distribution standard directed the fiduciary to model the lifestyle to which the settlor's wife was accustomed when the settlor was living. ${ }^{122}$

Although the ultimate result in Van Dusen is consistent with the terms of the trust and not surprising in the least, having to rely on judicial intervention led to exorbitant attorney's fees and costs, ${ }^{123}$ years in litigation, and ultimately a fractured relationship among the participants to the trust. ${ }^{124}$ By steadfastly maintaining its long-standing approach to distributions and not taking an affirmative role in deciding how the trust language applied to Virginia's and the other beneficiaries' changing needs, the trustee created, in the words of the parties and trial court, an "unworkable system for going forward." 125 Moreover, the trustee, when faced with its own clear distribution error, minimized the mistake's importance; no real communication occurred with Virginia until she was already angered and adversarial. ${ }^{126}$

So what purposes are served by using judges as touchstones for trustees? Both trustees and judges are imbued with decision-making

121. The appellate court found merit in Virginia's three primary arguments: first, that the trustee had not exercised its discretion to deny requests for principal distributions; second, that the trial court erred by approving the trustee's requirement that the beneficiary justify an increase in her current standard of living because the agreement ensured her the standard of living that existed during her marriage; and third, that the trustee should not have considered other sources of income when determining her need for distributions of trust principal. Id. at 520-26.

122. Id. at $522-23$.

123. Although not all of the parties' fees were disclosed, the appellate decision indicates that the remainder beneficiaries' attorney's fees and costs came to $\$ 274,556.67$. Id. at 525. It is likely that the settlor's wife and the trustee, separately represented, would have incurred equally large expenses, resulting in a collective bill of nearly one million dollars.

124. "The trial court denied Virginia's motion to remove the trustee, although it did not foreclose the parties agreeing to a resignation and replacement, and denied the motion to have an individual co-trustee appointed to serve with the institutional trustee." Van Dusen Trial Court, supra note 109 , at *17. The jurisdiction did not allow removal of the trustee without fault. But cf. In re McKinney, 67 A.3d 824, 826 (Pa. Super. Ct. 2013) (describing and invoking Pennsylvania trust law provision that allows trustee to be changed due to "substantial change of circumstances").

125. Van Dusen Trial Court, supra note 109, at*16-17.

126. See supra notes $114-17$ and infra note 250 . 
power and corresponding responsibilities. ${ }^{127}$ Although judges are not the only decision-makers whose conduct has tremendous impact on others' lives, ${ }^{128}$ how judges instill their decision-making process with legitimacy and, in so doing, inspire trust, has been the subject of significant research and scholarship. ${ }^{129}$ There are admittedly differences between what a judge does and what a trustee does, including that the former serves a public role while the latter acts in a private capacity, ${ }^{130}$ but both must exercise discretion in the face of competing interests, both must interpret and apply texts to fluid factual contexts, and both occupy a special position of power vis-à-vis the people whose lives they affect and whose property is at stake. ${ }^{131}$ Beneficiaries of private trusts are most frequently people with whom the trust's creator has personal and intimate ties, either through blood, marriage, or other affinity. Indeed, "[t]rusts are ... being used by broader segments of society than in the past, and with greater diversity of objectives (ranging from tax and probate avoidance, to property management late in life, to highly sophisticated multifamily, multigenerational plans of disposition)." ${ }^{\prime 132}$ Although creators often have

127. See David L. Ponet \& Ethan J. Leib, Fiduciary Law's Lessons for Deliberative Democracy, 91 B.U. L. REV. 1249, 1255 (2011) ("In the fiduciary relationship, the beneficiary is dependent on the fiduciary to act after her interests and the fiduciary is, accordingly, obligated to use her entrusted discretionary power in pursuit of the beneficiary's interests.").

128. Some early readers of this Article suggested that arbitrators and mediators, who, like trustees, deliberate in private and are often selected for their substantive knowledge about the matters in dispute, provide a more apt analogy. Although trustees' similarities to these private arbiters are noteworthy, the Article's focus on building trust in decision-making makes judges the most useful point of comparison primarily because their decision-making process has been the subject of such extensive study.

129. See infra notes $174-84$ and accompanying text.

130. See Mathilde Cohen, Sincerity and Reason-Giving: When May Legal Decision Makers Lie?, 59 DePAUl L. REV. 1091, 1099-1103 (2010) (describing the relationship between publicity and sincerity); Leib et al., supra note 18, at 728-29 (describing how fiduciaries' actions, unlike judges', are subject to further judicial review, but explaining that compliance with private fiduciary obligations is widespread "because the norms are so deeply rooted and function mostly extrajudicially").

131. Frankel, supra note 10, at 808-09; Leib et al., supra note 18, at 706-08, 718-19. Indeed, courts sometimes refer to trustees having to act "judiciously." See, e.g., Friedman v. Friedman, 844 So. 2d 789, 792 (Fla. Dist. Ct. App. 2003) ("Although the trustee of the trust in the instant appeal has absolute discretion to pay out income and principal to the beneficiaries, he still must exercise good faith and be judicious in the administration of the trust." (emphasis added)); Dunkley v. Peoples Bank \& Trust Co., 728 F. Supp. 547, 558 (W.D. Ark. 1989) (“[A] grant of even 'absolute discretion' does not absolve the trustee from liability for breaching his duty to act judiciously in the administration of the trust estate." (emphasis added)). The Uniform Trust Code recognizes the judicial analogy by allowing trustees to be removed from office for less than misconduct, when the beneficiaries so request and when removal is not inconsistent with the trust's material purposes. UNIF. TRUST CODE § 706(4) (amended 2010).

132. Halbach, supra note 63 , at 1883 . 
economic motivations, such as saving taxes or providing beneficiaries with creditor protection, ${ }^{133}$ they also have emotional motivations, such as love, fear, and jealousy. ${ }^{134}$ After all, leaving a legacy means designing a mechanism to promote your wishes for how your property will be administered after you die. The settlor may love her child but fear that the child will spend all of her property if she receives it outright. The settlor may love all of her children equally but fear that one will encounter greater need than the others as time passes. The settlor may love her spouse and want that spouse to have lifetime access to the property but fear that when the spouse no longer needs the property, he will divert it outside the family to a new spouse or children who are not the settlor's children. Private trusts are for the most part, then, about emotions, relationships, and families, ${ }^{135}$ however the family unit is defined. ${ }^{136}$ Even if the trustee is a professional, ${ }^{137}$ she is hired in part because she either knows or has been made familiar with the family's history and can make decisions about managing and distributing the family members' assets in ways that fit the different members' needs. ${ }^{138}$

Comparing trustees to judges helps illuminate ways in which trust law, trustee conduct, and trust decision-making depart from standards that have been characterized as trustworthy in the judicial context; besides that, the project of comparing the two is "worthwhile, possible, and perennially interesting." 139 As the next Part will illustrate, the qualities that define effective judges and facilitate principled and credible decision-making are helpful in evaluating how those who decide to use trusts to transfer their property might think about trust design and trustee

133. Sitkoff, supra note 3, at 674-77.

134. I have discussed the emotional component to estate planning elsewhere. See Deborah S. Gordon, Letters Non-Testamentary, 62 U. KAN. L. REV. 585, 590 (2014). In this recognition, I am not alone. See Cooper, supra note 2, at 1191 ("[M]any settlors engage in estate planning and establish trusts in order to benefit their chosen beneficiaries in a variety of ways-not only financially, but also personally and perhaps even spiritually."); Tritt, supra note 3, at 2582-83 (describing "trust law and practice" as "complex, highly idiosyncratic, and emotionally charged").

135. See ScOtT ON TRUSTS, supra note $3, \S 2.1 .4$ ("The Trust as a Relationship").

136. Gallanis, supra note 2, at 217 ("The garden-variety trust arises from the noncommercial transfer of property, typically within a family."); see also Frances Foster, The Family Paradigm of Inheritance Law, 80 N.C. L. REV. 199, 228-35 (2001) (describing limitations of traditional but pervasive definition of family as purely biological and offering alternatives).

137. See supra note 10.

138. See Leslie, supra note 6, at 83-86.

139. Leib et al., supra note 18 , at 702 . 
selection. Marrying flexibility to structure is what trust relationships require and what principled judicial decision-making provides. ${ }^{140}$

\section{THEORIES OF DECISION-MAKING: QUALITIES THAT DEFINE EFFECTIVE JUDGES AND FACILITATE PRINCIPLED AND CREDIBLE ADJUDICATION}

Starting with Justice Cardozo, ${ }^{141}$ modern jurists, scholars, and philosophers have debated the qualities that define an effective judge in a democratic society and "the relevant normative guideposts that should constrain or inform [judicial] interpretation." 142 While conversation about the judicial process is by no means over, ${ }^{143}$ certain principles have emerged as so well-accepted that they have been incorporated into codes of conduct that apply to judges of every type and in virtually every United States jurisdiction. ${ }^{144}$ As the preamble to the American Bar Association's 2010 Model Code of Judicial Conduct explains, our

140. RichaRd A. POSNER, REFLECTIONS ON JUDGING 355-57 (2013).

141. Benjamin N. Cardozo, The Nature of the Judicial Process 13 (1921).

142. Leib et al., supra note 18, at 699-700; see also POSNER, supra note 140, at 356-57 ("What we can expect in a very good judge, and 'find in abundance in Cardozo's opinions, are (1) a vivid, even dramatic, bodying forth of the judge's concerns, (2) a lucid presentation of arresting particulars - fodder for academic analysis, (3) a sense of the relatedness of these particulars to larger themes, (4) a point of view that transcends the litigants' parochial concerns ..., (5) a power of clear and forceful statement, and (6) a high degree of sensitivity to the expectations of one's audience."” (quoting Richard A. Posner, Cardozo: A Study IN REPutation 133 (1990))); Paul Horwitz, Judicial Character (and Does it Matter), 26 CONST. COMMENT. 97, 98 (2009) (recognizing that when discussing the judicial function, "we all stand in the shadow of Benjamin Cardozo's grand work").

143. See Leib et al., supra note 18, at 700 ("Justice Cardozo started the modern conversation about the role of the judge in American democracy, but no one has been able to complete it."); see also Jeffrey M. Chemerinsky \& Jonathan L. Williams, Measuring Judges and Justice, 58 DukE L.J. 1173 (2009) (describing symposium on empirical studies of judicial decision-making); Susan B. Haire \& Rorie Spill Solberg, Introduction the Behavior of Federal Judges, 97 JUDICATURE 71 (2013) (describing a symposium on a book about behavior of federal judges); Judith Resnick, Trial as Error, Jurisdiction as Injury: Transforming the Meaning of Article III, 113 HARV. L. REV. 924 (2000) (describing federal judiciary's transformative shifts in priorities throughout the century and the implications of those shifts on principled adjudication, at least in the federal courts); Helena Silverstein, Introduction to Symposium on Keith J. Bybee's All Judges Are Political-Except When They Are Not, 38 LAW \& SOC. INQUIRY 190 (2013) (describing symposium on a book about relationship between judging and politics).

144. See Jeffrey M. Shaman, Judicial Ethics, 2 Geo. J. Legal Ethics 1, 3-4 (1988); Keith A. Swisher, The Moral Judge, 56 DrAKE L. REV. 637, 666 (2008); see also Benjamin B. Strawn, Note, Do Judicial Ethics Canons Affect Perceptions of Judicial Impartiality?, 88 B.U. L. REV. 781, 78688 (2008) (tracing history of codes from ABA enactment of "Canons of Judicial Ethics" in 1924 through ABA enactment of the "Model Code of Judicial Conduct" which, in its 1990 form, was adopted by every state other than Montana). 
society depends on judges who "aspire at all times to conduct that ensures the greatest possible public confidence in their independence, impartiality, integrity, and competence." ${ }^{145}$ The stated purposes for these rules are to "fulfill the public trust" and "maintain and enhance confidence in the legal system."

The judicial process functions as it should when judges act with impartiality, integrity, and competence; they are able to convey these qualities to their audiences by providing mindful and sincere explanations of their reasoning. ${ }^{147}$ These elements of principled adjudication, and the ways that they are applied to judicial conduct, provide a useful touchstone for trustee conduct, too. Accordingly, the remaining sections describe how scholars, jurists, and commentators have thought about and questioned each of the foregoing essential components of judging. ${ }^{148}$ While a full exposition of how judges manifest these qualities in their day-to-day work is a task far beyond the reaches of this Article, even a simplified exploration of these essential elements of the judicial process, and the questions they raise especially when they are absent, is helpful in establishing a framework for building trust.

\section{A. Judicial Impartiality}

That a common law judge should be impartial in exercising her discretion is perhaps the most universally recognized, albeit fervently debated, component of a credible and principled judicial process. ${ }^{149}$ At

145. Model Code of Judicial Conduct Preamble 1 (2010).

146. Id. ("Inherent in all the Rules contained in this Code are the precepts that judges, individually and collectively, must respect and honor the judicial office as a public trust and strive to maintain and enhance confidence in the legal system.").

147. See Charles Gardner Geyh, The Dimensions of Judicial Impartiality, 65 FLA. L. REV. 493, 498 (2013) ("Plato recounts that in $399 \mathrm{BC}$, Socrates described a judge's responsibilities in the following way: 'Four things belong to a judge: to hear courteously, to answer wisely, to consider soberly, and to decide impartially." (citation omitted)); Swisher, supra note 144, at 657-61, 666-67 (describing a judge's prime directive as applying rules within context and a judge's prime virtue as open-mindedness).

148. Although judging also can involve collective action by multiple adjudicators, space constraints have dictated that this Article focus on decision-making by an individual. Similarly, a trust does not allow for a "jury"; in fact, it is interesting to think about whose peers would serve.

149. See Geyh, supra note 147, at 494 (“'Judicial impartiality' is a feel-good term, like 'puppies' and 'pie,' that no decent soul would denigrate."); Jeffrey M. Shaman, The Impartial Judge: Detachment or Passion?, 45 DePAul L. Rev. 605, 605 (1998) ("We expect our judges to be, above all else, impartial arbiters so that legal disputes are decided according to the law free from the influence of bias or prejudice. The principle of judicial impartiality is dictated by statutory and 
its most concrete, judicial impartiality means independence from control by forces or influences that are not relevant to the legal question at issue. ${ }^{150}$ Accordingly, a judge is expected to disqualify herself if she or any of her close associates has a personal financial interest in a case or a tie to one of the litigants or their representatives; indeed, even if there is no personal tie, a judge must recuse herself if her affinities raise an appearance of partiality and thereby cast suspicions on her motives. ${ }^{151}$ The reasons for judicial independence are manifest; were a judge to be personally associated in some way with the litigants or the result, or even appear to be so associated, the parties and the public might lose confidence in the judicial process, regardless of outcome. ${ }^{152}$ As

common law, is required by the Code of Judicial Conduct, and is essential to due process of law.... [but] [p] ure impartiality is an ideal that can never be completely attained. Judges, after all, are human beings ....”). See generally Charles E. Clark \& David M. Trubek, The Creative Role of the Judge: Restraint and Freedom in the Common Law Tradition, 71 YALE L. J. 255, 265 (1961).

150. See Geyh, supra note 147, at 498-509 (using non-legal sources to document different categories of partiality, including "judges who have personal interests in case outcomes; judges who have relational interests in case outcomes; judges who have political interests in case outcomes; and judges who have personal biases for or against case participants that are unattributable to the judges' personal, relational, or political interests."). The requirement that the judiciary remain independent from political or other insidious influence was so fundamental to Alexander Hamilton and his peers that they conferred life tenure on federal judges so they would not to be subject to political pressures that might come with reelection campaigns. THE FEDERALIST NO. 78, at 465, 469 (Alexander Hamilton) (Clinton Rossiter ed., 1961); see also Keith J. BYBEe, All Judges ARE POLITICALEXCEPT When They Are Not: ACCePtable Hypocrisies AND the Rule of LAW 6-13 (2010) (discussing political influences on state and federal judges).

151. Leslie W. Abramson, Appearance of Impropriety: Deciding When a Judge's Impartiality “Might Reasonably Be Questioned,"14 Geo. J. Legal Ethics 55, 57 (2000); see also In re Murchison, 349 U.S. 133, 136 (1955) ("'O]ur system of law has always endeavored to prevent even the probability of unfairness. To this end no man can be a judge in his own case and no man is permitted to try cases where he has an interest in the outcome."). Subpart (A) of section 2.11 of the Model CODE OF Judicial CONDUCT PREAMBLE, dealing with "Disqualification," requires a judge to disqualify herself "in any proceeding in which the judge's impartiality might reasonably be questioned."

152. See Abramson, supra note 151, at 66-67 (describing appearance of partiality standard and its application in federal and state courts as necessary "to maintain a high level of public respect for the judiciary"); Amanda Frost, Keeping Up Appearances: A Process-Oriented Approach to Judicial Recusal, 53 U. KAN. L. REV. 531, 532 (2005) ("Congress intended judges to recuse themselves in such cases so that 'justice satisfies the appearance of justice,' which will in turn 'promote public confidence in the integrity of the judicial process." ). On the other hand, a judge should not disqualify herself simply because a case presents a particularly difficult or controversial question or has the potential to lead to an unpopular result. See id. at 534 ("Judges are given life tenure and salary protections not just so they can hold their own against the other two branches of government, but also so that they can take positions opposed by the majority of the public."); $c f$. Sherrilyn A. Ifill, Do Appearances Matter?: Judicial Impartiality and the Supreme Court in Bush v. Gore, 61 MD. L. REV. 606, 618-19 (2002) (describing "duty to sit" doctrine that was specifically overturned but is still influential). Accordingly, the rule's nuances lie in the types of ties that are inappropriate or at least sufficiently questionable as to raise an appearance of impropriety and therefore a question about the judge's independence. Justice Frankfurter, for example, disqualified himself from a case involving two bus passengers who were complaining about music played during their morning 
discussed in Part IV, this ideal is particularly interesting when applied to trustees, who often have beneficial stakes in the trust property that are distinct from the interests they hold as decision-makers, because it exposes a potential vulnerability in building trust which, at the very least, must be anticipated and confronted. ${ }^{153}$ Indeed, what might seem at first to be a defect in the analogy because so many trustees are not impartial is useful because it exposes flaws in traditional notions about the wisdom of appointing family members as trustees.

Judicial impartiality, in a broader but more essential sense, means taking an open-minded approach to the issues in dispute, rather than being predisposed to a particular outcome. ${ }^{154}$ After all, the root of the word "prejudice" is "prejudge." 155 Thus, although "each judge comes to the bench with a unique background and personal philosophy," impartiality requires that she greet each legal problem with fresh eyes. ${ }^{156}$ What seems to be an indisputable idea, though, has spawned significant normative analysis about what judicial review should endeavor to be and significant positive analysis about what judicial review actually is. ${ }^{157}$

commute, stating, "My feelings are so strongly engaged as a victim of the practice in controversy that I had better not participate in judicial judgment upon it." Shaman, supra note 149, at 620 (quoting Public Utils. Comm'n v. Pollak, 343 U.S. 451, 467 (1952) (Frankfurter, J.)). In contrast, Justices Scalia and Ginsburg have declined to recuse themselves, respectively, from cases involving personal acquaintances and organizations with which they are involved. See Frost, supra note 152, at $531-33$.

153. See infra notes $312-21$ and accompanying text.

154. Shaman, supra note 149, at 619-24; Swisher, supra note 144, at 638; Patricia M. Wald, Some Thoughts on Judging as Gleaned from One Hundred Years of the Harvard Law Review and Other Great Books, 100 HARV. L. REV. 887, 888-90 (1987).

155. MERriam-Webster's COllegiate Dictionary 979 (11th ed. 2003); see also Geyh, supra note 147, at 498 ("The Oxford English Dictionary defines 'impartial' as '[n]ot partial; not favouring one party or side more than another; unprejudiced, unbiased, fair, just, equitable." (citation omitted)).

156. CARDOZO, supra note 141, at 112; see also, e.g., Frank B. Cross, What Do Judges Want?, 87 TEX. L. REV. 183, 232 (2008) ("The simple prescription that judges should do the 'good' thing ... places trust in the judiciary, deciding case by case, to assess the facts and law and policy of cases and - drawing upon their diverse individual backgrounds and ideologies - to ultimately reach a 'good' legal rule.... Judges are ideologically influenced in reaching their decisions, but they are far from pure ideologues. Judges certainly attend to the law, but they are not simply legalistic. Instead, they are balancers of various immediate and systemic interests at stake in litigation.”).

157. See generally Barry Friedman, The Politics of Judicial Review, 84 TEX. L. Rev. 257 (2005) (discussing and criticizing normative judicial review theory). Some of the dominant but opposing schools of thought are the "legalist" theory, the "attitudinal" theory, the "strategic" theory, and the "aretaic" theory. See Horwitz, supra note 142, at 102; Cross, supra note 156, at 187. Legalism, which is "the prevailing mindset of the American lawyer, even in a post-realist age" posits that judges do and should decide cases based on "a body of rules constituting the 'law' rather than by factors that are personal to judges" and that acceptable answers are "derived largely if not wholly from the legal materials at hand." Horwitz, supra note 142, at 102-03 (quoting RICHARD A. POSNER, HOW JUDGES THINK 41 (2008)). In contrast, the "attitudinal" model of judicial process "argues that judges can best be understood as 'acting purely on the basis of their policy preferences"” 
Though commentators agree that the adjudicative process loses credibility if litigants and the public view a judge as having decided a case before hearing and considering the evidence and arguments, how "real life" judges should conduct themselves is less straightforward.

Again, Justice Cardozo is of some help. He saw impartiality, and the consistency it fosters, as "one of the most fundamental social interests" of the law and explained that "[t]here must be nothing in [the judicial process] that savors of prejudice or favor or even arbitrary whim or fitfulness." 158 While a judge need not (and many would say cannot) detach herself from a lifetime of "inherited instincts, traditional beliefs, acquired convictions," Cardozo explained that a judge must endeavor to disregard her preconceived ideas every time she is interpreting and applying the law. ${ }^{159}$ Instead, she must rely on precedent, history, custom, logic and philosophy to ensure that the law develops symmetrically, but must also balance these factors against "the social interest served by equity and fairness or other elements of social welfare" in deciding cases. ${ }^{160}$ And when asked how a judge is to "know when one interest outweighs another" in order to reach a fair decision, Cardozo replied, "I can only answer that [she] must get [this] knowledge... from life itself." 161

Though eloquent, this directive does not provide much concrete guidance on the "pragmatic quest... for "impartial enough.",162

so, for example, judges appointed by a republican president will decide cases based on a republican ideology. Horwitz, supra note 142, at 105 (quoting Chad M. Oldfather, Judges as Humans: Interdisciplinary Research and the Problems of Institutional Design, 36 HOFSTRA L. REV. 125, 132 (2007)). Proponents of a "strategic" theory expand the attitudinal model to encompass not just immediate policy choices but also potential reactions to the decision that will impact the judge's long-term policy preferences. $I d$. at 105-06. Others theorize an "aretaic" or virtue-centered model that "focuses on the desirability of judges possessing "the judicial virtues-courage, temperance, judicial temperament, intelligence, and practical wisdom." Id. at 108 (quoting Lawrence B. Solum, The Aretaic Turn in Constitutional Theory, 70 BROOK. L. Rev. 475, 478 (2005)).

158. CARDOZO, supra note 141, at 112.

159. Id. at 112-13; see also David McGowan, Judicial Writing and the Ethics of the Judicial Office, 14 GeO. J. Legal ETHics 509, 514 (2001) ("[a]n ethical judge must demand of herself that she identify and understand her own biases and how they affect her reaction to a case.").

160. CARDOZO, supra note 141, at 112-13.

161. Id. at 113; see also Oliver Wendell Holmes, The COMmON LAW 1 (Cosimo, Inc. ed., 2009) (1881) ("The life of the law has not been logic: it has been experience."); Wald, supra note 154, at 895-97 (describing "the audacity of Oliver Wendell Holmes, Benjamin Cardozo, and Learned Hand to assert the legitimacy of judicial discretion in a common law regime"); Shaman, supra note 149, at 610-17 (contrasting Justice Holmes's detachment with Justice Cardozo's passion).

162. Geyh, supra note 147, at 510, 541; Patricia M. Wald, A Response to Tiller and Cross, 99 Colum. L. REV. 235, 235 (1999) ("Judging is a complex, case-specific, and subtle task ...; reducing the process to the level of checking a box on a ballot discredits the responsibility with which ... judges have been entrusted ....”). 
Recently, Professor Charles Geyh has provided a systematic theory that conceptualizes impartiality as occupying three "distinct dimensions"procedural, political, and ethical-depending on which participants' goals are being considered. ${ }^{163}$ The procedural dimension relates to the parties to a case, who seek a fair process and are "more apt to accept adverse outcomes" if they perceive that they were treated in a way that protected them from the perils associated with a partial judge. ${ }^{164}$ If a judge acts prematurely to dispose of a case, for example, the parties will perceive the judge as having prejudged the matter and the process as therefore unfair. ${ }^{165}$ Geyh explains that for parties, "the interest in judicial impartiality is personal to them, acutely felt, case-specific, and shaped by firsthand experience."166 Geyh's second dimension of impartiality involves members of the public, who may not be directly affected by the outcome in a particular case but seek institutional legitimacy generally. ${ }^{167}$ In comparison to the parties, "the public's interest in an impartial judiciary is less personal than philosophical or ideological, more diffuse than acute, systemic rather than case-specific (although highly publicized cases can breed systemic concerns), and shaped less by firsthand experience than by impressions gleaned from public discussions on the acceptability of judges to the body politic."168 Though trusts, because they are private, are not available for public scrutiny, this second dimension of trustee impartiality, with its institutional focus, relates more closely to the creators - settlors and their estate planning lawyers - who establish these relationships and set their parameters. ${ }^{169}$ Geyh's third dimension of impartiality relates to the judge, for whom this quality is central to her "ethical" view of self. ${ }^{170}$ Although judges have personal interests in the procedural and political dimensions, their "self-identity as good judges is tethered to the oath they have sworn to be impartial-an

\footnotetext{
163. Geyh, supra note 147, at 497.

164. Id. at 511 .

165. Id. at 522; see also id. at 514-22 (discussing how this interest is regulated by the Due Process clauses of federal and state constitutions, by disqualification rules, and by rules of litigation procedure, all of which must be balanced against the systemic costs that the procedural rules engender); infra notes 216-23 and accompanying text (discussing work of Professor Tom Tyler on process).

166. Geyh, supra note 147 , at 511 .

167. Id. at 511-12.

168. Id. at 512; see also id. at 539-40 (discussing how this interest is regulated by mechanisms for judicial removal, selection, and oversight).

169. See infra notes 306-07 and accompanying text.

170. Geyh, supra note 147 , at 512 .
} 
oath judges have taken for centuries."171 How much partiality is tolerable will "depend[] on which objective is at issue and the constraints to which the applicable system of regulation is subject." 172 As discussed in Part IV, this tripartite approach to impartiality as it relates to audience is particularly helpful when thinking about how trustees, even those who are not independent, can act impartially. ${ }^{173}$

\section{B. Judicial Integrity}

Canon 1 of the Model Code mandates that a judge "act at all times in a manner that promotes public confidence in the independence, integrity, and impartiality of the judiciary."174 "Integrity," which connotes morality or notions of right and wrong, is easier to define in its absence. ${ }^{175}$ A judge who accepts bribes or kickbacks, for example, lacks integrity. ${ }^{176}$ Similarly, a judge who decides a matter based on an arbitrary mechanism, such as a roll of the dice or the party's physical appearance on a particular day or even the judge's reliance on substances that distort her thinking, for example, lacks integrity. ${ }^{177}$ In addition to undermining confidence in the law that the judge has made, this type of conduct is dangerous because judges can "give momentum to- or stoptrends developing in the legal profession."

171. Id.; see also id. at 523-29 (discussing how this interest is regulated by codes of judicial conduct and shows why reversal, rather than discipline, is appropriate if a judge makes an honest mistake).

172. Id. at 527; see also id. at 541-51 (providing examples of how different cases involving same-sex marriage, pleading requirements, disqualification, and free speech test all three dimensions of impartiality).

173. See infra notes $302-07$ and accompanying text.

174. MODEL CODE, supra note 145, R. 1.2.

175. Gerald Lebovits, Alifya V. Curtin \& Lisa Solomon, Ethical Judicial Opinion Writing, 21 GeO. J. Legal Ethics 237, 239 (2008) ("It is easy to define extreme misconduct in the negativelike taking bribes in exchange for favorable rulings. It is difficult, however, to define what moral conduct is in the affirmative."); see also Joan Didion, On Morality, in SLOUChING TowardS BETHLEHEM 157 (1968) (questioning the meaning of morality and the use of the term in society).

176. See Stephanie Chen, Pennsylvania Rocked by 'Jailing Kids for Cash' Scandal, CNN (Feb. 24, 2009, 10:15 AM), http://www.cnn.com/2009/CRIME/02/23/pennsylvania.corrupt.judges/; Ben Evans, Judge on Trial Before Senate, WASH. TIMES (Sept. 13, 2010), http://www.washington times.com/news/2010/sep/13/judge-on-trial-before-senate/.

177. See Swisher, supra note 144, at 656 n.87 (describing judicial coin-tossing and resulting discipline); Robert Patrick, Judge Rejects Plea Deal for Former St. Clair County Judge in Drug Case, St. Louis Post DisPatch (Feb. 26, 2014), http://www.stltoday.com/news/local/crime-andcourts/federal-judge-rejects-plea-deal-for-former-st-clair-county/article_5bc071d3-eb8a-5925-bcecb0868780b479.html (describing Missouri judge's ten-year drug addiction).

178. Lebovits et al., supra note 175 , at 239. 
Accordingly, the ideal judge displays an impeccable and virtuous character. ${ }^{179}$ And we expect this integrity to appear both in the judge's private life and her public one. When Sol Wachtler, chief judge of the New York Court of Appeals, was revealed as having stalked his longtime companion, a matter wholly unrelated to what many would characterize as a brilliant judicial career, the public's and the bar's confidence in him was shaken, and Judge Wachtler resigned in disgrace. ${ }^{180}$

But a judge need not be amoral, corrupt, or criminal to lack integrity. A judge lacks integrity any time she misuses or abuses her power. If she overreaches to decide an issue that is not presented to the court, she lacks integrity. She also acts without integrity when she refuses to decide a matter that is properly before her court, just because the matter is unpleasant or difficult. ${ }^{181}$ Indeed, to the extent that we see judges as recipients of a "public trust," we demand that they wrestle with society's worst dilemmas, even if the results of their decisions are unpopular ones. ${ }^{182}$ Accordingly, judicial integrity requires a judge to rule with restraint on matters appropriately before her but to refuse to overreach when those matters are not presented to her directly. ${ }^{183}$ As described in Part IV, ideas about judicial integrity are particularly helpful in responding to the idea that trusts are foremost managerial and commercial, rather than moral, devices. ${ }^{184}$

\section{Judicial Competence and Diligence}

The Model Code of Judicial Conduct requires a judge to "be faithful to the law and maintain professional competence in it." 185 This directive

179. See Horwitz, supra note 142, at 99 (review of books that focus on "identifying the character traits that distinguish the admirable, excellent, or virtuous judge.").

180. See Catherine S. Manegold, Judge and Heiress: The Rise and Fall of a Private Affair, N.Y. TIMES (Nov. 15, 1992), http://www.nytimes.com/1992/11/15/nyregion/judge-and-heiress-the-riseand-fall-of-a-private-affair.html.

181. See Geyh, supra note 147, at 513 ("Ethics rules forbid recusal except when disqualification is required because '[j] udges must be available to decide the matters that come before the court,' while the 'rule of necessity' directs otherwise disqualified judges to hear cases when no other judge would be qualified to sit." (quoting MODEL CODE, supra note 145, R. 2.7, cmt. 1)).

182. Leib et al., supra note 18, at 740-52 (describing “deliberative engagement").

183. See Frederick Schauer, Giving Reasons, 47 Stan. L. REV. 633, 644-56 (1995); Cass R. Sunstein, Foreword: Leaving Things Undecided, 110 HARV. L. REV. 4, 7 (1996).

184. See infra notes 288-301 and accompanying text.

185. Shaman, supra note 149, at 617-18 (citing ModEL CODE OF JUDICIAL CONDUCT PREAMBLE (2010)). 
seems obvious and easy to satisfy; after all, judges usually reach their posts because they are lawyers who have demonstrated some proficiency in and affinity for the law and have a desire to immerse themselves more fully in it. "Professional competence" implies diligence, too; judges must decide their cases promptly so that parties do not languish in the courts. ${ }^{186}$ Arguably the least disputed requirements for a principled judicial process, the duties of competence and diligence do, however, reveal gaps in the decision-making process and thus help to highlight some effective methods to fill those gaps.

For example, judges increasingly face cases that present complex and highly specialized matters about which the adjudicators have little expertise or experience. ${ }^{187}$ Consider, for example, having to opine on the extent of patent protection for genetic sequences and modifications, ${ }^{188}$ or the taxability of modern artwork, ${ }^{189}$ or human egg donations. ${ }^{190}$ Competence seems more elusive when faced with such esoteric but important disputes. ${ }^{191}$

186. Samuel K. Benham, Note, Judicial Purgatory: Strategies for Lawyers, 58 DRAKE L. ReV. 585, 588-89 (2010); see also Charles Gardner Geyh, Adverse Publicity as a Means of Reducing Judicial Decision-Making Delay: Periodic Disclosure of Pending Motions, Bench Trials and Cases Under the Civil Justice Reform Act, 41 Clev. St. L. Rev. 511, 513-20 (1993) (describing "defensible delays," which are those attributed to "burgeoning caseloads," too few judges, structural inefficiency, and case complexity, and "indefensible delays," which are "precipitated by nonstructural inefficiency, indecision, inertia, belligerence or disability.").

187. See POSNER, supra note 140, at 54-95 (describing challenges posed by "external" complexity, which means complexity that is generated outside the legal system).

188. See, e.g., Ass'n for Molecular Pathology v. Myriad Genetics, Inc., 133 S. Ct. 2107, 2111 (2013) (holding that a "naturally occurring DNA segment is a product of nature and not patent eligible merely because it has been isolated, but that cDNA is patent eligible because it is not naturally occurring"); Bowman v. Monsanto Co., 133 S. Ct. 1761, 1764 (2013), reh'g denied, 134 S. Ct. 24 (2013) (holding that a farmer who buys genetically modified and patented seeds may not reproduce those seeds through planting and harvesting without the patent holder's permission).

189. See, e.g., Calder v. Comm'r, 85 T.C. 713, 714 (1985) (determining "fair market value" for estate tax purposes of over 1000 gouache paintings); Estate of Mitchell v. Comm'r, 101 T.C.M. $(\mathrm{CCH}) 1435$, at *12 (T.C. 2011) (discussing valuation of paintings by prominent American Western artists); Estate of Elkins v. Comm'r, No. 16597-10, 2013 WL 892399, at *87-88 (T.C. Mar. 11, 2013) (determining "fair market value" for estate tax purposes of various works of art, including "a large Henry Moore sculpture, a Pablo Picasso drawing, and a Jackson Pollock painting.").

190. See Perez v. Comm'r, No. 9103-12, 2015 WL 393047 (T.C. Jan. 22, 2015) (Holmes, J.) (positing whether compensation received for the sale or donation of human eggs and related services is taxable income).

191. Specialty courts have been proposed as a response to such complexity but have been met with widespread dissatisfaction. See POSNER, supra note 140, at 94-95; see also Chad M. Oldfather, Judging, Expertise, and the Rule of Law, 89 WASH. U.L. REV. 847, 850 (2012) (concluding that although specialized judges may have a claim to expertise "in the weak sense that they will be more efficient in reaching conclusions than non-experts" the content of their decisions is unlikely to "differ in some qualitative respect from—or be in some general sense 'better than'-those of their 
When the requisite judicial knowledge involves learning an unfamiliar area of law, judges can attain competence through good, oldfashioned research and analysis. After all, some of this country's highest ranking and most respected judges came to the bench with experience that differs substantially from the legal issues they now encounter regularly. ${ }^{192}$ As every first-year law student knows, practicing law is fundamentally about analogizing and distinguishing existing cases, statutes, and rules in order to apply them to new and unfamiliar questions; ${ }^{193}$ facility with traditional and online forms of legal research should allow even a novice judge to achieve competence in an unfamiliar area of law. ${ }^{194}$ And the adversarial system is designed to incentivize the lawyers to help the judge in this endeavor, albeit often in ways that advance the parties' respective positions. ${ }^{195}$ Even novel questions of first impression should not test a judge's legal competence to reach a decision; a probate judge, for example, who is considering the very interesting and difficult questions presented by a smartphone "last will and testament" has a body of established will doctrines upon which she can rely. ${ }^{196}$

When the expertise required of a judge involves particularly complex, novel, or unfamiliar facts, however, traditional venues of legal learning may not be adequate to attain "competence." 197 Again, think patenting of genes or taxability of human body parts. In such cases, judges might invite attorneys or professors who have particular background to submit "friend of the court" briefs. ${ }^{198}$ These amicus

generalist counterparts").

192. See generally Gregory L. Acquaviva \& John D. Castiglione, Judicial Diversity on State Supreme Courts, 39 Seton Hall L. Rev. 1203, 1232-38 (2009) (describing prior judicial and employment experience for state judges); Benjamin H. Barton, An Empirical Study of Supreme Court Justice Pre-Appointment Experience, 64 FLA. L. REV. 1137, 1138-62 (2012) (describing prior experience of Supreme Court justices).

193. See Linda H. Edwards, Legal Writing ANd ANALysis 17-21 (3d ed. 2011); Emily Sherwin, A Defense of Analogical Reasoning in Law, 66 U. CHI. L. REV. 1179, 1179-81 (1999); Cass R. Sunstein, Commentary, On Analogical Reasoning, 106 HARV. L. REV. 741, 741-42 (1993).

194. Judges can sustain their legal competence by participating in some form of continuing education. POSNER, supra note 140, at 331-37.

195. See Neal Devins \& Saikrishna B. Prakash, Reverse Advisory Opinions, 80 U. CHI. L. Rev. 859, 864-65 (2013) ("In deciding what the law is (and is not), a judge consults her own accumulated legal wisdom, the briefs, the oral arguments, and even Google search results.").

196. See Gordon, supra note 134, at 630 n.238 (describing questions of first impression involving iPhone and tablet wills).

197. See Jed S. Rakoff, Are Federal Judges Competent? Dilettantes in an Age of Economic Expertise, 17 FORDHAM J. CORP. \& Fin. L. 4 (2012); see also POSNER, supra note 140, at 54-94 (discussing the competency of judges).

198. See Ruben J. Garcia, A Democratic Theory of Amicus Advocacy, 35 Fla. ST. U. L. ReV. 315, 315-16 (2008) (defining amicus curiae briefs). 
curiae briefs, even if they are not neutral, can highlight concerns that might be less apparent to someone who does not face the same situations on a regular basis. ${ }^{199}$ Likewise, expert testimony is a way for a court to become educated and therefore competent on esoteric questions. ${ }^{200}$ Though experts hired by litigants offer opinions that are inherently partisan, and therefore must be vetted as reliable before they are offered to a jury, ${ }^{201}$ judges can use the expert testimony to learn about the technical and complex issues involved in the case without necessarily adopting the expert's conclusions. ${ }^{202}$ Because the judge ultimately is accountable for the decision and its results, she must evaluate expert testimony like other facts and interpret and apply that testimony through an exercise of her reasoning and discretion. ${ }^{203}$ Trustees, like judges, rely on expertise from external sources. ${ }^{204}$ As Part IV discusses, the extent to which judges seek, use, and rely on this source of knowledge can provide

199. See id. at 316-18 (discussing how use of amicus curiae briefs has flourished and examining whether courts should limited filings). See generally Samuel Krislov, The Amicus Curiae Brief: From Friendship to Advocacy, 72 YALE L.J. 694 (1963) (describing historical and modern evolution of amicus curiae briefs, including how they can provide helpful information to courts and highlight implications of courts' rulings). Though amicus briefs are less prevalent in trial proceedings, there are times when they are appropriate. See, e.g., Michael F. Smith, Litigating Cases with Questions of First Impression, 81 DEF. COUNS. J. 101, 103 (2014).

200. Frederick Schauer \& Barbara A. Spellman, Is Expert Evidence Really Different?, 89 Notre DAME L. ReV. 1, 11 (2013) (“[A]s legal questions become ever more technical, whether because they involve difficult scientific questions or complex financial transactions or something else, expertise is becoming more rather than less necessary."); FED. R. EvID. 702 advisory committee's note to 2000 amendment ("Yet it might also be important in some cases for an expert to educate the factfinder about general principles, without ever attempting to apply these principles to the specific facts of the case. For example, experts might instruct the factfinder on the principles of thermodynamics, or bloodclotting, or on how financial markets respond to corporate reports, without ever knowing about or trying to tie their testimony into the facts of the case.").

201. See, e.g., Kumho Tire Co., v. Carmichael, 526 U.S. 137, 149 (1999) ("the trial judge must determine whether the testimony has 'a reliable basis in the knowledge and experience of [the relevant] discipline.”' (quoting Daubert v. Merrell Dow Pharm., Inc., 509 U.S. 579, 592 (1993))). Some have argued that the same gatekeeping function is needed for judges because they are no better than jurors in evaluating evidence or deliberately disregarding information that is inadmissible. See Schauer \& Spellman, supra note 200, at 11 \& n.50 (citing sources); Andrew J. Wistrich et. al., Can Judges Ignore Inadmissible Information? The Difficulty of Deliberately Disregarding, 153 U. PA. L. REV. 1251, 1260 (2005).

202. POSNER, supra note 140, at 297-98 \& n.11 (discussing how judges might appoint "neutral" expert witnesses and citing sources).

203. In valuation cases, for example, "the Tax Court frequently adopts a compromise value even if the parties did not offer specific testimony of that value, provided that it is within a range of figures that the evidence supports." Diana S.C. Zeydel \& Norman J. Benford, Valuation Principles and Recent Developments: Practical Guidance for the Estate Planner, 34 REAL PROP. PROB. \& TR. J. 207, 213 (1999).

204. See infra notes $267-68,281-84$ and accompanying text. 
guidance to trustees on their parallel solicitation and reliance on "experts." "205

\section{Judicial Credibility through Mindful Rhetoric}

Judicial impartiality, integrity, and competence go a long way toward enhancing the legitimacy of our legal system's decision-making process and building trust in it. This credibility is essential because, without it, litigants might as well resolve cases by way of arbitrary or self-help mechanisms and save themselves enormous time, money, and agitation. $^{206}$ But in order to inspire such confidence, the audiences for the decision must understand how it was reached. ${ }^{207}$ When a judge provides her audiences with the bases for her decision, whether through a written opinion or an oral one, she provides access to the legal reasoning that underlies and has driven the result. ${ }^{208}$ In an essay celebrating the

205. See infra notes $280-87$ and accompanying text.

206. See Lebovits et al., supra note 175 , at 244 ("The law forbids vigilante, or 'self-help,' justice. If individuals believe they will receive unexplained outcomes in the judicial forum, reliance, self-help might become the norm."); James L. Gibson, Judging the Politics of Judging, in WHAT'S LAW GOT TO Do WiTH IT 282-86 (Charles Gardner Geyh, ed. 2011) (describing legitimacy theory and its application to the judiciary). Increasingly, because of delays, uncertainties, and mounting expenses, parties opt to resolve their disputes outside of the courts. See Resnick, supra note 143, at 928, 936-37; Susan Sturm \& Howard Gadlin, Conflict Resolution and Systemic Change, 2007 J. DisP. RESOL. 1, 2 (2007). While this private and unofficial justice offers certain economic efficiencies, it threatens to deprive litigants - and those with less powerful voices - of their day in court and to lead to unpredictable and sometimes inconsistent results. Harry T. Edwards, Alternative Dispute Resolution: Panacea or Anathema?, 99 HARV. L. REV. 668, 679 (1986); Resnick, supra note 143, at 999, 1000; Peter L. Murray, Privatization of Civil Justice, 15 WiLlametTe J. INT'L L. \& DisP. RESOL. 133, 141 (2007).

207. See Lon L. Fuller, The Forms and Limits of Adjudication, 92 HARV. L. REV. 353, 388 (1978) ("[T]he fairness and effectiveness of adjudication are promoted by reasoned opinions. Without such opinions the parties have to take it on faith that their participation in the decision has been real, that the arbiter has in fact understood and taken into account their proofs and arguments."); Ruth Bader Ginsburg, The Obligation to Reason Why, 37 U. FLA. L. REV. 205, 221 (1985) ("Even if silent judgments are in fact well considered, the audience for court decisions is understandably suspicious. A judgment expressing no reasons presents the appearance of arbitrariness. Our [circuit] promises a decision with no waiting time if the parties stipulate that they will forgo an opinion. In my nearly five years on the court, not a single litigant has ever invoked the 'prompt decision but no opinion' prescription. The parties to an appeal, particularly the losers, want to know the reason why."); David L. Shapiro, In Defense of Judicial Candor, 100 HARV. L. REV. 731,737 (1987) ("[R]easoned response to reasoned argument is an essential aspect of [the judicial] process. A requirement that judges give reasons for their decisions - grounds of decision that can be debated, attacked, and defended - serves a vital function in constraining the judiciary's exercise of power.").

208. See Lani Guinier, Foreword: Demosprudence Through Dissent, 122 HARV. L. REV. 4, 11 (2008) (describing Justice Breyer's use of an oral dissent through which he "appealed to shared and heartfelt values, not just compelling logic and clear reason . . . and seemed to sense that the premises 
hundredth anniversary of the Harvard Law Review, then District of Columbia Circuit Judge Patricia Wald observed that "[f]or a conscientious judge, the simple obligation to write an opinion persuasively explaining the outcome of a case is a profound constraint on judicial discretion."209 Her then colleague Judge, now Justice, Ruth Bader Ginsberg echoed these sentiments five years later when she explained that "the effective judge ... strives to persuade, and not to pontificate." 210 An essential component of the judicial process, then, is rhetorical. ${ }^{211}$

That principled judging commands not only an impartial, thoughtful, and diligent consideration of the case but also a reasoned explanation, rather than a "blind announcement," of the result is not controversial. ${ }^{212}$ But this component of the judicial process raises a number of more nuanced questions in its application, including: for whom is the explanation intended; what form should that explanation take; and, if an explanation is proffered, what ensures that it sets forth the judge's actual reasoning, thereby satisfying the credibility goal, rather than a selectively deceptive reason provided solely to rationalize or insulate the result? ${ }^{213}$

behind the logic, the stories and not just the explanations, really mattered."); Chad M. Oldfather, Writing, Cognition, and the Nature of the Judicial Function, 96 GEO. L.J. 1283, 1344-45 (2008) (describing how the act of writing can help judges examine and test their conclusions); Patricia M. Wald, The Rhetoric of Results and the Results of Rhetoric: Judicial Writings, 62 U. CHI. L. REV. 1371,1372 (1995) ("One of the few ways [judges] have to justify our power to decide matters important to our fellow citizens is to explain why we decide as we do."); Nancy A. Wanderer, Writing Better Opinions: Communicating with Candor, Clarity, and Style, 54 ME. L. REv. 47, 49-52 (2002) (describing how clearly written and well-reasoned judicial opinions are foundational to American jurisprudence).

209. Wald, supra note 154, at 904; see also Shapiro, supra note 207, at 737 ("[C]andor is the sine qua non of all other restraints on abuse of judicial power, for the limitations imposed by constitutions, statutes, and precedents count for little if judges feel free to believe one thing about them and to say another.").

210. Ruth Bader Ginsburg, Speaking in a Judicial Voice, 67 N.Y.U. L. REV. 1185, 1186 (1992).

211. Rhetoric has been defined as "simply the art of persuasion." Jane B. Baron \& Julia Epstein, Is Law Narrative?, 45 BufF. L. REv. 141, 146 (1997); see also James Boyd White, Law as Rhetoric, Rhetoric as Law: The Arts of Cultural and Communal Life, 52 U. CHI. L. REV. 684, 684 (1985) (citing the definition from Plato's Gorgias that rhetoric is "the art of persuading the people about matters of justice and injustice in the public places of the state."). For more general discussions on rhetoric, see SONJA K. Foss et AL., CONTEMPORARY PERSPECTIVES ON RHETORIC 47 (3d ed. 2002).

212. See Richard A. Posner, Judges' Writing Styles (And Do They Matter?), 62 U. CHI. L. REV. 1421, 1448 (1995); see also Wald, supra note 208, at 1375 ("Rhetoric will always be tied to [results]."); Micah Schwartzman, Judicial Sincerity, 94 VA. L. REV. 987, 1002-05 (2008) (describing reasons why providing justifications enhances judicial legitimacy). But see Schauer, supra note 183, at 657 (" $[\mathrm{R}]$ eason-giving can thus be seen as contingent rather than necessary, a style of decisionmaking with disadvantages of excess commitment that might at times outweigh its advantages.").

213. See Shapiro, supra note 207 , at $731 \& \mathrm{n} .4$ ("Th[e] idea—-that judges at times may properly 
Starting with audience, judicial explanations in any form are foremost intended for those who will feel their direct impact: the litigants. Without question, there are numerous others who might read, learn from, and debate a judicial opinion, including lawyers, other judges, law students, scholars, and the general public, ${ }^{214}$ but the parties are the primary audience seeking to understand the result. After all, they may want to take some further action because of it, such as appealing an incarceration, collecting on a judgment, distributing assets of an estate, or marrying the person they love. Accordingly, there is a practical justification for wanting an available and accessible explanation. ${ }^{215}$ There is a theoretical reason too that aligns with the objectives of credibility and confidence described above; the parties have placed their problem in the judge's hands and no doubt want to understand why the relief they seek has been granted or denied. Providing reasons for the result affords the parties respect and shows that the decision was sufficiently important to merit the judge's keen attention. ${ }^{216}$ Such explanations are equally valuable when they are issued by trial courts as by appellate courts. ${ }^{217}$ In both cases, the judge and those directly affected by the ruling are part of a community that shares a common interest in reaching a fair outcome. As Professor Frederick Schauer has

sacrifice openness and candor for the sake of other goals - has been expressed in many ways by a number of observers."); see also Cohen, supra note 130, at 1100-02 \& n.34-35 (summarizing and citing to legal scholarship in favor of and against the "inherent requirement of the judicial function to give candid reasons"); Schwartzman, supra note 212, at 988-89 \& n.2 (describing debate about judicial sincerity).

214. Lebovits et al., supra note 175, at 246. See generally Wanderer, supra note 208, at 52-55 (describing different audiences for judicial opinions).

215. Wanderer, supra note 208, at 51.

216. Mathilde Cohen, Reason-Giving in Court Practice: Decision-Makers at the Crossroads, 14 COLUM. J. EUR. L. 257, 258 (2008) ("Reason-giving shows respect. It demonstrates that attention has been paid to the special features of a case and the parties involved."); Michael M. O'Hear, Explaining Sentences, 36 FLA. ST. U. L. REV. 459, 481 (2009) ("Properly understood, procedural justice requires not just the possibility that the judge could have considered and rejected the defendant's arguments on neutral, rational grounds, but also some meaningful reassurance that the judge actually did so."); Wanderer, supra note 208, at 51 ("By showing respect for the people affected by their rulings and encouraging this form of participatory democracy, courts encourage respect for the judicial system and widespread acceptance of their opinions.").

217. See Oldfather, supra note 208, at 1285 \& n.6, 1289-91 (citing appellate courts that criticize trial courts for not providing reasoning and exploring reasons why trial courts would explain their decisions); see also Wald, supra note 154, at 907 ("[G]reat judges of the past are celebrated not for the way they voted, nor for the number of times they were affirmed or reversed by the Supreme Court, but rather for their ability to devise apt, just, and understandable rules of law; they are held up as models because they were able to bring to clear expression thoughts that in lesser minds would have remained too vague and confused to serve as adequate guideposts for human conduct."). Following this rationale, even private forms of justice should require a decision-maker to explain the result to the parties, notwithstanding that the result will not bind others in the future, because it will help parties regulate and adapt, if necessary, their future conduct. 
stated, "giving reasons is a way of opening a conversation" which ultimately can make "the subject of the decision feel[] more a part of the decision, producing the possibility of compromise and the respect for a final decision that comes from inclusion." 218

This idea that explanations reinforce the decision-maker's legitimacy is supported by empirical studies that examine how and when individuals perceive a system as fair. Recognizing that legal authorities of any kind are effective only when they are able "to gain acceptance for their decisions among the members of the public with whom they personally deal," Professor Tom Tyler has found that a legal authority's process and "process oriented problem solving" is key to trust. ${ }^{219}$ Tyler's work examines how individual members of the public respond to negative outcomes of "service" encounters with legal authorities, where those members are seeking some form of help, and "regulatory" encounters, where the legal authorities are trying to bring the member of the public's conduct in line with established rules. ${ }^{220}$ In both instances, the studies reveal that contrary to general intuition "both the willingness to accept outcomes and feelings about the decision-maker are dominated by reactions to the process used by that decision-maker to deal with the issues involved in a personal encounter" more than they are tied to outcome. $^{221}$ Thus, for example, “'citizens' accounts suggest that they focus on whether they are treated with respect and dignity, whether [authorities'] actions are explained, and whether they are listened to and have their views considered."222 According to these psychological studies, taking the time to explain a decision will encourage members of the public to trust the judge, to see her decision as legitimate, and to abide by it to a greater degree than they would do if she simply exerted power, force, or control. ${ }^{223}$

218. Schauer, supra note 183 , at 658.

219. See Tom R. Tyler, Trust and Law Abidingness: A Proactive Model of Social Regulation, 81 B.U. L. Rev. 361, 362-63 (2001) [hereinafter Tyler, Trust]. See generally Tom R. TYLER, Why People Obey the Law (2006); Tom R. Tyler eT Al., Social Justice in a Diverse Society 83 (1997).

220. Tyler, Trust, supra note 219 , at 364-65.

221. Id. at 367; see also id. at 372-91 (describing empirical study and specific findings).

222. Id. at 394; see also id. at 384 ("The approach that is most consistent with the research reviewed here involves efforts to treat citizens fairly and respectfully, listening to them and communicating explanations for [authorities'] actions.").

223. Id. at 391-405; Leib et al., supra note 18, at $718 \mathrm{n} .104$; see also Oldfather, supra note 208, at 1284 (taking the time to articulate the rationale for an opinion can help a judge to be more mindful); Schauer, supra note 183, at 657-58 ("Under some circumstances, the very time required to give reasons may reduce excess haste and thus produce better decisions."); R. George Wright, The 
Accepting the relatively straightforward idea that the judicial process functions best when decisions are explained, legal scholars and judges have avidly debated the more nuanced elements of content and form that serve to enhance clarity, to "constrain arbitrariness," and to fortify the system of stare decisis. ${ }^{224}$ For example, some commentators have observed how the most seasoned and well-respected judges employ a particular style ${ }^{225}$ when they deliver their rulings and, conversely, how certain courts obfuscate their rulings through confusing linguistic choices. ${ }^{226}$ Other scholars have promoted the use of specific rhetorical techniques, ${ }^{227}$ which make judicial decisions more accessible to their audiences and therefore more worthy of respect. ${ }^{228}$ Yet others have advocated for restrained and minimalist decisions, ${ }^{229}$ for candid and sincere decisions, ${ }^{230}$ and for moral and ethical decisions. ${ }^{231}$ Although varied in approach, these diverse scholars share the common objective of proposing ways that judges can help enhance legitimacy and build

Role of Intuition in Judicial Decisionmaking, 42 Hous. L. REv. 1381, 1420-21 (2006) (deciding cases necessarily involves intuition but "an opinion accompanying an intuitionist outcome can itself amount to reasonable evidence that the judge has taken full, careful, empathetic, and detailed account of all of the main interests and concerns of the opposing and other affected parties.").

224. Lebovits et al., supra note 175, at 244-46; see also Schauer, supra note 183, at 657-58 (describing justifications for reason-giving, including showing respect and commitment and counteracting "bias, self-interest, insufficient reflection, or simply excess haste...."); Wanderer, supra note 208, at 49 ("Judicial scholars in the United States ... emphasize the importance of writing a reasoned justification for the outcome in a case as a way of achieving the goals of our judicial system: (1) guiding the participants in the legal process, (2) persuading judges, officials, and citizens that the court has reached the proper resolution of a dispute, (3) limiting judicial arbitrariness, and (4) legitimizing any judicial departures from apparently established law.").

225. See Richard A. Posner, How Judges Think 63 (2008) (pointing to Holmes, Brandeis, Cardozo, and Hand as "examples of judges who succeeded by their example in altering the norms of opinion writing"); Posner, supra note 212, at 1426-32 (describing "pure" style of Justices Cardozo, Brandeis, Frankfurter, Brennan and the second Harlan, in contrast with the "impure" style of Justices Holmes, Douglas, Black, Jackson and Learned Hand, with Judge Friendly in the middle).

226. See Laura E. Little, Hiding with Words: Obfuscation, Avoidance, and Federal Jurisdiction Opinions, 46 UCLA L. REV. 75, 140 (1998); see also POSNER, supra note 140, at 237-38 (describing "signs of bad judicial writing").

227. Devices might include: figurative language, see, e.g., Wanderer, supra note 208, at 66-69; natural language, see, e.g., Wald, supra note 208, at 1417-18; and empathic dialogue, see Mitchell F. Crusto, Empathic Dialogue: From Formalism to Value Principles, 65 SMU L. REV. 845, 865-66 (2012); Lynne N. Henderson, Legality and Empathy, 85 MicH. L. REV. 1574, 1575-79, 1628 (1987).

228. See POSNER, supra note 140, at 255-58 (providing rules that will help "both formalist and realist, and whether judge or law clerk" write "a better, a more readable, and also a more honest opinion").

229. See Schauer, supra note 183 , at $654-56$ (describing problems that stem from generalized reasoning); Cass R. Sunstein, supra note 183, at 7 (1996) ("Of course it is important to study what judges say; but it is equally important to examine what judges do not say, and why they do not say it.").

230. See Schwartzman, supra note 212, at 990-91; Shapiro, supra note 207, at 736-50.

231. See Lebovits et al., supra note 175, at 286-309; Swisher, supra note 144, at 655-56. 
confidence in the decision-making process. As Professor Nancy Wanderer has explained, "[w]hen people do not feel committed to judicial pronouncements because they do not understand them or because they feel alienated from the judicial system itself, cynicism about legal institutions flourishes, potentially leading to outright disrespect for the law."232

All of this discussion boils down to the fact that those who care about their claims also care about the reasons why a decision-maker reached a particular outcome. Were a judge to write that she spun a Roulette wheel or threw a dart to decide a case, however, we might be less sanguine about judicial explanations because reasons like these, albeit achingly sincere, do not enhance the judicial process's credibility. ${ }^{233}$ This point may seem exaggerated but, in fact, audiences do express skepticism as to whether the reasoning that judges provide really and regularly reflects the grounds upon which those judges have decided the cases before them. ${ }^{234}$ After all, if we trust what Justice Cardozo wrote, and his many successors have analyzed, then we recognize that the judicial process involves both objective and subjective components. $^{235}$ Accordingly, while a judge may purport to be relying on legitimate rationales for deciding a case in a particular way, she may actually be deciding the case on other, and potentially less defensible, grounds than the ones her decision proffers. ${ }^{236}$ Her legalist tendencies and training may be leading her to describe law-based reasons for the result, even though her attitudinal tendencies (her politics) may actually

232. Wanderer, supra note 208, at 51; see also POSNER, supra note 140, at 355 (noting that the factual complexity of modern federal litigation "makes good judicial writing more rather than less important, because judges have to learn to write about complexity in ways that they and their audience . . can understand"); Schwartzman, supra note 212, at 990-91 ("[J]udges are charged with the responsibility of adjudicating legal disagreements between citizens. As such, their decisions are backed with the collective and coercive force of political society, the exercise of which requires justification. It must be defended in a way that those who are subject to it can, at least in principle, understand and accept ... [Judges] who fail to give sincere legal justifications violate this condition of legitimacy.").

233. See Schauer, supra note 183, at 636 (discussing bad reasons for a decision); Swisher, supra note 144, at $656 \mathrm{n} .87$ (discussing arbitrariness of judicial coin-flipping).

234. See Cohen, supra note 130, at 1099; see also Martin Shapiro, Judges as Liars, 17 HARV. J.L. \& PUB. POL'Y 155, 156 (1994) ("Courts and judges always lie. Lying is the nature of the judicial activity.").

235. See CARDOZO, supra note 141, at 112-13.

236. See BYBEE, supra note 150, at 20-22 (describing public suspicions of judicial hypocrisy); Wright, supra note 223, at 1420-24 (describing role of judicial intuition). 
be dictating the outcome. Or even if her reasons are arguably legitimate, she may be disguising them for other, quite valid purposes. ${ }^{237}$

Professor Keith Bybee has recognized this public and scholarly skepticism about the source of judicial decision-making and has explained why such skepticism is far less troubling than it may at first appear. $^{238}$ In repeated surveys testing how the public views influential court decisions on important topics like health care reform and presidential election recalls, for example, a majority of participants opined that the judges' decisions did not reflect the actual reasons for the results, which the public viewed as based on "personal or political beliefs." 239 Even as the public doubted that judges were candidly providing all of the reasons for their decisions, Bybee observed, the same participants in the surveys demonstrated nearly universal confidence in the judicial process; most people who were polled believed that the "single most important influence" on a judge, regardless of forum, was the judge's "analysis and interpretation of the law." 440 Because of this tenacious belief that judges are seeking to do the best job possible within the confines of systemic and human limitations, litigants continue to place trust in and rely on the process. ${ }^{241}$

237. See Cohen, supra note 130, at 1115-21; Schwartzman, supra note 212, at 988-89.

238. See Keith J. Bybee, The Rule of Law is Dead! Long Live the Rule of Law!, in WHAT's LAW Got To Do With It?: What Judges Do, Why They Do It, and What's at StaKe, 306-07 (Charles Gardner Geyh ed., 2011) [hereinafter Bybee, The Rule of Law is Dead]; BYBEE, supra note 150, at 5-6 ("Public skepticism about whether judges actually mean what they say is potentially corrosive, but it also points to an enabling dynamic that makes possible the exercise of legal power.").

239. Keith J. Bybee, All Judges Are Political—Except When They Are Not: A Response, 38 LAW \& Soc. INQUiRY 215, 217 (2013) [hereinafter Bybee, A Response] (quoting Kaiser Family Foundation study); see also BYBEE, supra note 150, at 16-18 (describing polls designed to survey public opinion of state courts, federal courts, and "courts in general" that reflect similar findings); Bybee, The Rule of Law is Dead, supra note 238, at 308-13 (same).

240. Bybee, A Response, supra note 239, at 217. See also BYBEE, supra note 150, at 17-18 ("A large majority of the public appears to believe that the courts are principled institutions where political pressure and partisan rivalry have no place; at the same time, a large majority of the public also appears to believe that partisanship influences the judicial process."); Bybee, The Rule of Law is Dead, supra note 238, at 308-13 (stating that "the public simultaneously believes in the evenhandedness of the federal courts and doubts the degree to which the federal judges actually stick to the law").

241. See BYBEE, supra note 150 , at $102-03$ ("[I]t is possible to see, contrary to conventional understandings, that law is not facing a grave threat to its stability. It is true that our system is beset by suspicions of hypocrisy generated by clashing public perceptions of judicial action.... [T] judicial process continues to endure because it suits the individuals it governs-at least if we understand these individuals to be motivated by a messy mix of principled belief and passionate demands."). 
In sum, although scholars have posited and challenged the many ways the foregoing traits manifest themselves, there is little doubt that principled adjudication requires a judge to refrain from pre-judging a matter, to work to understand the facts and issues as they arise and change over time, and to provide a mindful explanation of her reasoning, all in the service of reaching an outcome that is acceptable to the participants in the process. Part IV considers how these basic but essential components of judicial decision-making shed light on the creation and administration of private donative trusts.

\section{APPLYING THE ANALOGY}

This Part contends that the impartiality, integrity, competence, and candor we expect from judges can help trustees, settlors, beneficiaries, and their respective counsel think about how to meet the donative trust's challenges of fractionalized ownership and temporal uncertainty. Starting in reverse order, the first section below argues that just as judges who explain their decisions build confidence in the judicial process, so too can trustees engender trust from beneficiaries by providing explanations to accompany their actions. This understanding can have a profound effect on the way trustees and settlors think about disclosure obligations and reliance on trust protectors. Judicial competency standards, too, help refine ideas not only about how a trustee is selected but also about whether she should be allowed to delegate her duties. Judicial integrity ideals justify the moral element in the trust relationship even in the world of today's management trust, administered primarily by professional fiduciaries. Finally, principles of judicial impartiality and independence, which present the sharpest contrast between judges and trustees, expose some interesting problems that ultimately bear on trustee conduct and identity.

\section{A. Trustee Credibility and Explanations}

The idea that the judicial process gains legitimacy when judges provide reasons for their decisions has implications for how a trustee should interact with trust beneficiaries on an ongoing basis and over the term of the trust. As noted above, a key quality of a well-respected decision-making process is thoughtful explanation of the basis for a 
decision. ${ }^{242}$ Such explanation can reinforce the decision's legitimacy because even when parties are disappointed with an outcome, they are more apt to accept the results - and the process-when the judge explains her underlying rationale. ${ }^{243}$ One reason for this acceptance is the audience's recognition of the effort that explanation requires; this investment shows that the decision-maker has taken the matter seriously, has deemed it important, and has worked to resist the arbitrariness that can ensue when discretion is unbounded. ${ }^{244}$

Mindful, regular, and open communication can have the same crucial impact on building and maintaining confidence in trustees and their decision-making processes. Historically, trustees and settlors have resisted disclosure to trust beneficiaries, citing privacy and protective concerns. $^{245}$ Even today, where many jurisdictions require some degree of trustee transparency, the disclosure commonly associated with trusts is not designed or intended to further the relationship among the settlor, trustee, and beneficiaries or to facilitate acceptance of how the trustee is administering the trust. Rather, legislatures and commentators contemplate disclosure in the form of a copy of the trust agreement and an accounting or "report" that lists trust earnings, distributions, and expenditures. ${ }^{246}$ The beneficiaries can use this "report" to enforce their interests and keep trustees accountable, both of which are admirable but inherently adversarial goals. ${ }^{247}$ If a trustee makes an error, she can list it in the account, rely on the beneficiaries to notice and question it, and, to the extent they do not do so, use it to bind off any future objections once the objection period has expired. ${ }^{248}$ Because this form of disclosure

242. See supra notes 206-41 and accompanying text.

243. See supra notes 216-23 and accompanying text.

244. See supra notes 215-18 and accompanying text.

245. See supra notes 62-68 and accompanying text.

246. See UNIF. TRUST CODE $\S 813$ (amended 2010); Gallanis, supra note 63, 1600-03; Kevin D. Millard, The Trustee's Duty to Inform and Report Under the Uniform Trust Code, 40 REAL PROP. PRoB. \& TR. J. 373, 379-82 (2005).

247. David M. English, The Uniform Trust Code (2000): Significant Provisions and Policy Issues, 67 MO. L. REV. 143, 199 (2002) (explaining that "[t]he duty to keep the beneficiaries reasonably informed of the administration of the trust is a fundamental duty of a trustee, for only by being informed can the beneficiaries know of and enforce their interests" (emphasis added)).

248. See In re Trust No. T-1 of Trimble, 826 N.W.2d 474, 488 (Iowa 2013) ("Implicit in the protective nature of the duty to account is that the beneficiaries will be able to take action against the trustee should they discover the trustee has breached one of its duties."); Estate of Alden v. Dee, 35 A.3d 950, 959-60 (Vt. 2011) (agreeing with fiduciary that providing beneficiaries with annual accountings started statute of limitations period running on filing objections to trustee conduct); see also Gallanis, supra note 63, at 1627 ("First, and centrally, the duty to inform should result in the beneficiaries having sufficient information to safeguard their interests."). But see Marsman v. 
provides no explanation for the trustee's decision-making process, though, it does not serve the goals that candor achieves in the judicial process. Cases often refer to beneficiaries who have lost confidence in their trustees because the trustees have not explained adequately the basis for their decisions and thereby treated the beneficiaries with the procedural respect they expect and deserve. ${ }^{249}$

Trustees and trust scholars recognize disclosure obligations as secondary, rather than as a fundamental part of the trustee's fiduciary duties; the unfortunate result for anyone who cares about the proper and long-term functioning of the trust relationship is the inevitable breakdown that lack of transparency breeds rather than the trust that explanations can inspire. ${ }^{250}$ Take, for example, the case of Rollins $v$. Rollins, ${ }^{251}$ which provides a representative depiction-through the

Nasca, 573 N.E.2d 1025, 1031 (Mass. App. Ct. 1991) ("That [the beneficiary] assented to the accounts is also no bar to recovery by his estate. The judge found that he was in the dark as to his rights to receive principal ....").

249. See Smith v. SunTrust Bank, 754 S.E.2d 117, 121-22, 126 (Ga. Ct. App. 2014) (reversing summary judgment for trustees based on statute of limitations where corporate trustee agreed to exercise its discretion and distribute all trust income to settlor's daughter, a co-trustee and one of many trust beneficiaries, without inquiring as to other beneficiaries' needs, but wrote a single letter to the other beneficiaries announcing this decision and telling them to "make a request for the Trustee to consider an income distribution to you" if they disagreed at any time); O'Riley v. U.S. Bank, N.A., 412 S.W.3d 400, 410-11 (Mo. Ct. App. 2013), transfer denied (Oct. 29, 2013) (noting that although the "Trustee's distribution decisions were the product of a thoughtful evaluation and review process and consistent with the terms of the Non-Marital Trust and Missouri law," the institutional trustee (through its trust officer and trust management committee) did not appear to communicate their conduct and findings to the plaintiff-beneficiaries). In the facts of Van Dusen, rather than communicate directly with the trust beneficiary about an uncontroverted distribution error, the trustee appeared to downplay the error and then argue that by acknowledging it during the course of litigation, the beneficiary had been placed on notice and should therefore be precluded from raising any claims regarding the mistake. See supra notes 114-17 and accompanying text. But it was the trustee's failure to engage the beneficiary and explain the mistake in the first place that appears to have angered the beneficiary enough to lose confidence in the trustee after years of accord. See supra note 115. The trial court decision is filled with excuses for the trustee's lack of candor. See Van Dusen Trial Court at *4 ("Mrs. Van Dusen had free and ready access to the document itself, and has had multiple attorneys working on her behalf who were available to explain or examine this language if she had questions. Moreover, there is no evidence that Mrs. Van Dusen ever sought explanation or clarification of this language from Wells Fargo."); id. at *8 ("Virginia Van Dusen argues that the Trustee violated its duty of loyalty by failing to make a $\$ 49,247.42$ principal distribution, requested by Mrs. Van Dusen in 2001, and subsequently failing to inform Mrs. Van Dusen that it had not been made. The Trustee argues that this was potentially due to an error or oversight by the Trustee, but that such an error has since been corrected, as the Trustee distributed the funds in 2011.").

250. See supra notes $206-41$ and accompanying text.

251. There were three decisions in the Rollins case. The Georgia Supreme Court decision can be found at Rollins v. Rollins, 755 S.E.2d 727 (Ga. 2014) [hereinafter Rollins Supreme]. The intermediate appellate court decision can be found at Rollins v. Rollins, 741 S.E.2d 251 (Ga. App. 2013) [hereinafter Rollins Intermediate]. The trial court decision is not available but is quoted in the two appellate decisions [hereinafter Rollins Trial]. 
various court opinions and the parties' appellate briefs - of how trustee disclosure obligations are ordinarily perceived and fulfilled. The Rollins family patriarch established a series of trusts for the benefit of his nine grandchildren and more remote descendants and funded those trusts with interests in a multi-billion dollar assembly of family entities. ${ }^{252}$ The settlor's two sons and a family friend served as trustees, and the sons also controlled the family entities. ${ }^{253}$ The lawsuit arose out of discontent on behalf of four of the settlor's grandchildren who sought information from the trustees - their father and uncle-about transactions, both at the trust level and at the entity level, and accused the trustees of breaching various fiduciary duties, also in both roles. ${ }^{254}$ In refusing to order an accounting at the entity level, the Rollins trial court noted that the trustees had failed to provide any disclosure, but that the beneficiaries "ultimately received a report on trust assets and 'complete relief' on their requests for an accounting through discovery." 255 The intermediate appellate court reversed and ordered the trustees to account on the entity level, reasoning that although the trusts did not hold controlling interests in the entities, the same people were in control and therefore able to provide this information. ${ }^{256}$ This expansive (and quite surprising) disclosure order appeared to stem from the appellate court's suspicion that the trustees were reluctant to communicate openly about the "complex web" of interactions between the entities and the trust. ${ }^{257}$ Although the Georgia Supreme Court vacated and remanded the order requiring the trustees to account at the entity level, it acknowledged that the appellate court "may ultimately prove to be correct." 258 Emphasizing the equitable nature of trusts generally and disclosure requirements in particular, the highest court reversed because the intermediate court had failed to consider and accord any deference to the trial court's discretion. ${ }^{259}$ The three Rollins

\footnotetext{
252. Rollins Intermediate, 741 S.E.2d at 253.

253. Id.

254. Id. at 253-54.

255. Rollins Supreme, 755 S.E.2d at 729 (quoting Rollins Trial).

256. Rollins Intermediate, 741 S.E.2d at 255-56.

257. Id. at 253. Language that supports the court's suspicions includes the decision's repeated reference to the sons' functional control of the trust through their control of the entities, id. at 25556 ; the court's recognition of the potential for "clever manipulation of corporate structure," $i d$. at 258 (internal quotations omitted); and the court's observation that actions affecting trust interests were taken "without notifying the beneficiaries," $i d$. at 260 . Where the sons did write to the beneficiaries, they were accused of mischaracterizing their status vis-à-vis the corporate entities; the court referred to this communication as "alleged subterfuge." Id. at 261.

258. Rollins Supreme, 755 S.E.2d at 730.

259. Id. at 730. The Georgia Supreme Court also reversed the holding that a "heightened
} 
decisions are interesting because of how they depict trustees' and courts' expectations and understanding of disclosure obligations: minimal at best.

Appling a judicial paradigm would significantly alter how trustee disclosure is viewed based on the idea that the explanation behind decision-making itself is crucial to building and maintaining trust. ${ }^{260}$ In other words, disclosure not only satisfies the important goals of monitoring trustee conduct and providing finality but also enhances the beneficiaries' confidence in the procedures employed by the trustee to reach her decisions about distributions and investments. ${ }^{261}$ Although a trustee should not be expected "to inform the beneficiaries of every aspect of administration of the trust or every request for distribution made to the trustees, ${ }^{262}$ disclosure, whether in the form of a writing or a family meeting, should be aimed at helping the beneficiaries understand the trustee's process of decision-making rather than simply providing "information about trust assets necessary to protect the beneficiaries' interest."263 To the extent that such disclosure displays the trustee's effort and care, it has the potential to make the parties to the trust feel more committed to and respectful of the conduct, because they will be able to understand it and feel included and recognized by it. ${ }^{264}$

Because this form of disclosure is about building and maintaining a relationship among the parties to the trust, a trustee's communication

trustee-level fiduciary standard" should apply to the sons' management of the corporate entities. The court reasoned that the settlor, who was a sophisticated businessman with full knowledge of the delicate role he was assigning his children, had constructed the trusts so that the decision-making rested at the entity rather than the trust level. Moreover, the trusts owned only a minority interest in the entities. Id. at 730-31. Even this part of the decision, though, was remanded to the Georgia Court of Appeals, which was directed to apply the correct fiduciary standard "when considering the trustees' conduct with regard to their management of the corporate family entities held within the trusts." Id. at 731 .

260. Cf. Schwartzman, supra note 212, at 989 ("Proponents of greater candor in the courts have argued that transparent decision making constrains the exercise of judicial power, makes judges more accountable to the law, provides better guidance to lower courts and litigants, promotes trust and reduces public cynicism, and strengthens the institutional legitimacy of the courts." (citations omitted)).

261. See Leib et al., supra note 18, at 718 n.104 (relying on work of Tom Tyler to explain that "the fiduciary principle's notion of trust is a structural feature of the relationship at issue that facilitates ongoing willingness by a dependent party to abide by the fiduciary's decision. It is often the power itself, once conferred, that renders the beneficiary in a position where she needs to trust, even if she is in a psychological state of distrust").

262. Estate of Alden v. Dee, 35 A.3d 950, 962 (Vt. 2011).

263. Id.; see also Gallanis, supra note 63, at 1616 ("Put differently: the more the agent's decisions are known to (or discoverable by) the principal, the more likely it is that the agent will choose to act in the principal's best interests.").

264. See Wanderer, supra note 208, at 51; see also Schwartzman, supra note 212, at 990-91 (discussing sincerity and candor). 
with a "trust protector," rather than directly with beneficiaries, is unlikely to provide an acceptable substitute. ${ }^{265}$ Communicating with an information surrogate does not foster an exchange with the beneficiaries nor enhance their understanding of the trustee's decision-making. Analogous to a judicial decision that reaches all audiences except for the parties involved, disclosure to a trust protector artificially creates more distance between the parties to the relationship instead of uniting them.

Potential objections to recognizing that enhanced disclosure is essential to administering a trust and fostering confidence in that administration include that transparency will increase administration costs, require trustees to engage in conduct for which they are potentially unequipped, and provide fodder for lawsuits by greedy or disgruntled beneficiaries. While a trust and its trustees may enjoy short-term efficiencies by simply acting, the long-term functioning of the trust relationship - and therefore, the long-term transaction costs - are likely to suffer. Moreover, although this preferred form of disclosure might appear radical, in fact, many trustees - those who manage to avoid becoming embroiled in disputes and ultimately litigation - communicate regularly with their beneficiaries in just the way that a judicial analogy would encourage. ${ }^{266}$ Regular family meetings and periodic reports describing market conditions, investment tactics, distribution plans, and overall strategies for the trust allow these relationships to flourish. This approach is taken by mindful and experienced trustees who value their long-term relationships with trust creators and the objects of their bounty. Families that enjoy this type of relationship with trustees continue to seek services from those trusted members and advisors for generations.

Objections to enhanced disclosure also can be seen as an opportunity for improving trustee selection. Settlors choose trustees for any number of reasons: financial savvy, potential longevity, wisdom, experience, family awareness, cost, or recommendations from estate planning lawyers. Understanding that a trustee's role involves maintaining both property and relationships over time and being responsible not only for substance but also for process will impact a decision about who best fits this role. Just because an institution, for example, has a solid reputation for sound investing will not necessarily mean that it is a good candidate to serve as trustee, especially if that position contemplates an ability to

265. See Gallanis, supra note 63, at 1624-26.

266. See, e.g., In re Trust No. T-1 of Trimble, 826 N.W.2d 474, 479 (Iowa 2013). 
explain the decision-making process to the beneficiaries. For example, will the institution put in place, and charge for, excessive layers of service to address this concern? Whether to select a family member, an institution, a professional individual, or some combination of the foregoing is not a decision to be made lightly. The potential trustee's ability to relate information to the beneficiaries should factor into this analysis.

In sum, providing a candid explanation of the basis for decisionmaking is not only key to the trustee demonstrating to the other parties to the trust that she has done her job, but is also crucial to their ongoing confidence that, as time passes, the trustee will continue to administer the property in a way that serves all parties' interests.

\section{B. Trustee Competence}

The judicial quality of competence translates quite smoothly to the law of trusts. Like judges, trustees should be expected to understand both the "law" and the "facts" that bear on their decision-making. What competence regarding the law might mean for trustees is that they understand the terms of the trust instrument and how existing default rules would fill any open spaces. ${ }^{267}$ To the extent a trustee does not understand the meaning of the governing document or how the common law and statutes affect its interpretation and their conduct, it would be appropriate for the trustees to "research" their obligations by hiring professional advisors like lawyers and accountants ${ }^{268}$ and even, like judges, to seek forms of continuing education.

What competence regarding the facts might mean for trustees is that they should understand their beneficiaries' full financial and personal circumstances, including their needs and risk tolerance, before making distributions. ${ }^{269}$ This requirement goes hand-in-hand with the disclosure and explanation described in the prior section; without inquiring about a

267. See supra note 40 (discussing trust default rules); see also Langbein, Mandatory Rules, supra note 35, at 1105 ("The law of trusts consists overwhelmingly of default rules that the settlor who creates the trust may alter or negate.").

268. SCOTT ON TRUSTS, supra note $3, \S 17.3$ at 1174; see also Spurgeon \& Ciccarello, supra note 42 , at 1386-89 (distinguishing between attorney acting as fiduciary and acting as legal advisor to a fiduciary).

269. Marsman v. Nasca, 573 N.E.2d 1025, 1030 (Mass. App. Ct. 1991) ("action of trustee is 'arbitrary' where he 'is authorized to make payments to a beneficiary if in his judgment he deems it wise and he refuses to inquire into the circumstances of the beneficiary"' (quoting SCOTT ON TRUSTS $\S 187.3$ (Fratcher 4th ed. 1988))). 
beneficiary's needs, a trustee will lack competence to make distribution decisions. ${ }^{270}$ A recent New York case involving a disabled trust beneficiary provides a stark example of trustee incompetence and "a clarion call for all fiduciaries of trusts." ${ }^{271}$ The subject trust in In re $J P$ Morgan Chase Bank was a multi-million dollar special needs trust ${ }^{272}$ that the grantor established for the benefit of her "severely disabled" autistic son. ${ }^{273}$ The trustees - an institution and an attorney-were given "absolute discretion" to make payments to or for the benefit of the named beneficiary, but an accounting for the trust revealed that the trustees expended negligible sums for the beneficiary's care. ${ }^{274}$ Upon further investigation by the surrogate's court, the individual trustee admitted that "he had never visited [the residential home] to ascertain [the beneficiary's] condition nor, more critically, his needs" nor had he "expended a single dollar on [the beneficiary's] behalf in almost three years." 275 The corporate trustee's response to inquiry displayed even greater incompetence; the bank tried to excuse its inattention by claiming a "lack of institutional capacity to ascertain or meet the needs of this severely disabled, institutionalized young man." ${ }^{276}$ The judge found these excuses inadequate and suggested that the trustees hire a "care manager," who thereafter was able to visit with the beneficiary, ascertain his needs, and report those needs to the fiduciaries. ${ }^{277}$ "[O]nce the Trustees were required to make themselves knowledgeable about [the beneficiary's] condition and his needs, and the availability of services that would enable them to provide for those needs," they used the trust funds for "the purposes his deceased mother anticipated and so deeply desired," and the beneficiary began to recover and thrive. ${ }^{278}$ Not surprisingly, the court held that the trustees had violated their fiduciary

270. See id. ("That there is a duty of inquiry into the needs of the beneficiary follows from the requirement that the trustee's power 'must be exercised with that soundness of judgment which follows from a due appreciation of trust responsibility." (citations omitted)).

271. In re JP Morgan Chase Bank, N.A., 956 N.Y.S.2d 856, 857 (N.Y. Sur. Ct. 2012).

272. For a recent article defining and describing "special needs trusts," see Robert Whitman, Disinheritance: An Alternative for the Special Needs Trust, 41 Est. Plan. 36, 36 (2014).

273. In re JP Morgan Chase Bank, N.A., 956 N.Y.S.2d at 857.

274. Id. at 859-60. More specifically, approximately three thousand dollars was spent on a "care manager" suggested to help with the beneficiary, amounting to less than one percent of the trust assets, over the five years of the trust's existence; during this same time, the trustees were paid more than $\$ 52,000$ in fiduciary commissions and more than $\$ 11,000$ in attorney fees. Id. at 860 .

275. Id. at 861 .

276. Id.

277. Id. at $861-65$.

278. Id. at $865-66$. 
duties of care and loyalty because simply keeping the assets safe was inadequate; "basic principles of trust administration and fiduciary obligation," the judge explained, mandate that trustees "take appropriate steps to keep abreast of [the beneficiary's] condition, needs, and quality of life, and to utilize trust assets for his actual benefit." 279 In other words, to be competent, a trustee must investigate any areas where her expertise or knowledge about the beneficiary is incomplete.

Factual competence also means that trustees should understand not only the beneficiaries but also the trust property. Again, this guidepost for principled trust decision-making affects trustee identity because the settlor should only select a trustee who is able to manage and invest the trust property competently. ${ }^{280}$ But this guidepost also involves trust governance standards once a trustee has been appointed and, more specifically, calls into question the modern rule that allows trusteeseven those that are sophisticated-to delegate investment responsibilities. $^{281}$ Traditional trust law held trustees accountable for losses that arose from their advisors' investment decisions and also prohibited trustees from using trust funds to pay third parties who essentially were doing the trustees' jobs, such as managing the trust portfolio. $^{282}$ Modern prudent investment law "has abrogated the traditional prohibition on delegating investment responsibilities and has instead sought to encourage such delegation" to ensure that the people charged with making investment decisions understand portfolio theory. ${ }^{283}$ Justifications for allowing this delegation include that, today, trustees must be familiar with different forms of investments in order to diversify adequately and will incur increased costs if they have to hire advisors to teach them about these investments as opposed to simply delegating the duty altogether. ${ }^{284}$ But this rule essentially absolves a trustee from liability for poor investment decisions once she has selected an advisor and told the advisor about the trust. ${ }^{285}$ Such complete relief from responsibility can have "potentially pernicious effects," including, as Professor Stewart Sterk argues, encouraging all fiduciaries to hire (pay

\footnotetext{
279. Id. at $867-68$.

280. See SCOTT ON Trusts, supra note 3, Ch. 17 (Trustee's Duties).

281. See supra notes 52-53 and accompanying text.

282. Sterk, supra note 51, at 865-66.

283. Sterk, supra note 51, at 854; see also SCOTT ON TRUSTS, supra note 3, § 17.3.

284. See supra notes 52-53 and accompanying text; Sterk, supra note 51, at 854.

285. See Sterk, supra note 51, at 885, 899; SCOTT ON TRUSTS, supra note 3, § 17.3; UNIF. PRUDENT INVESTOR ACT $\S 9(\mathrm{c})$ (1994); UNIF. TRUST CODE $§ 807$ (c) (amended 2010).
} 
for and rely on) investment advisors even if the trustees have the requisite expertise, encouraging less sound investments, and, in the case of an insolvent advisor, shifting the burden of losses from the trustee, who selected the advisor, to the beneficiaries, who did not. ${ }^{286}$

The competence component of the trustee-as-judge paradigm helps demonstrate why it is appropriate to leave responsibility for making competent investment decisions in the trustee's ultimate discretion, even if she hires advisors to help her do so. Like judges who might be unfamiliar with particularly tricky fact-based questions that affect case outcomes, trustees understandably might be unfamiliar with financial instruments that modern trust investment rules expect them to understand and master. ${ }^{287}$ Trustees, like judges, should be allowed to rely on "experts" for help, especially if the trustee is a friend or family member. But using an experienced investment advisor to provide guidance should not be synonymous with ceding responsibility for an essential component of the trustee's job. Again, that form of delegation saps the beneficiaries' trust in the trustee. Instead, trustees should be allowed to pay these experts to provide advice, listen to the advisors' recommended investment plans, but choose the approach that best matches the trust's other requirements, including risk tolerance and beneficiary needs.

\section{Trustee Integrity}

Judicial integrity requirements echo the fiduciary duty of loyalty and thereby reflect and help justify the moral obligations inherent in fiduciary law, even at a time where trusts have increasingly become about asset management. One concern with the judicial paradigm is that the law is already in danger of over-romanticizing the role of fiduciary and none more so than trustee, ${ }^{288}$ conferring additional prestige on trustees by comparing them to judges will hardly provide an effective counter-point to what has been criticized as "pulpit-thumping rhetoric" about trustees generally. ${ }^{289}$ While modern trust law fundamentally altered the trustee's

286. See Sterk, supra note 51, at 899-904.

287. See supra notes 51-55 and accompanying text.

288. See Meinhard v. Salmon, 164 N.E. 545, 546 (N.Y. 1928) (Cardozo, J.); Frankel, supra note 10 , at $829-30$.

289. Langbein, Contractarian Basis, supra note 2, at 629; see also Alexander, supra note 10, at 777-79 (arguing that "[ $\mathrm{t}] \mathrm{he}$ characteristic moral tone of judicial opinions about fiduciaries reflects the influence of a distinctive role-schema that judges associate with fiduciaries" that, in turn, leads to less trustworthy results in cases alleging breach of fiduciary duties). 
duties and powers vis-à-vis investments, it did not have a similar effect on the trustee's responsibilities for distributing funds impartially and fairly. ${ }^{290}$ In that regard, the modern trustee still resembles the trustee of old - the equitable feoffee-who was charged with deciding when trust property was to be paid out to or for the benefit of one or another of its beneficiaries or reinvested and held for the future. The moral obligation that originated with the trust's birth in equity, ${ }^{291}$ even if it arguably has lost some vitality in the face of today's expansive management powers and duties, continues to ring true where the fiduciary is considering how to weigh her personal interests against those of the beneficiaries or how to weigh those beneficiaries' competing needs.

More broadly, though, the trustee-as-judge paradigm highlights why the rhetoric of morality cannot be easily severed from discussions about trust law. First, as Professor Tamar Frankel has explained, fiduciary relationships center on the idea of altruism, meaning that "once an individual undertakes to act as a fiduciary, he should act to further the interests of another in preference to his own."292 Expecting and requiring that a trustee display integrity benefits the beneficiaries and settlor, whom the trustee serves, and, in exchange, encourages their faith in the trustee's decision-making. ${ }^{293}$ In fact, "the moral feature of fiduciary law forms a bridge between altruism and individualism by focusing on ... not[] merely the interests of others, but also the collective good . . ..294 More simply, this focus helps build the very trust that fosters both personal and professional relationships. ${ }^{295}$ Second, the rhetoric of morality and its corresponding expectation that trustees display integrity helps trustees understand the standards to which they are being held, including that they are serving those who occupy a more vulnerable

290. See supra notes $42-60$ and accompanying text.

291. See Frankel, supra note 10, at 831 (positing that courts may have imposed high moral standards on fiduciary conduct "because of the historical jurisdictional authority over fiduciaries in the ecclesiastical and equity courts" which "imposed sanctions based on religion and morality, and not merely on force.").

292. Frankel, supra note 10, at 830.

293. See id. ("[O]nce a person becomes a fiduciary, the law places him in the role of a moral person and pressures him to behave in a selfless fashion, to think and act for others.").

294. Id. at 832; see also Leib et al., supra note 18, at 729 ("[R]einforcement of the fiduciary principle through law is just one way to signal and frame the more basic moral norms that the relationship triggers and that the law recognizes. As a general matter, we tend to see large-scale compliance with private fiduciary obligations because the norms are so deeply rooted and function mostly extrajudicially."); FitzGibbon, supra note 85, at 305 (fiduciary relationships "facilitate the doing of justice, ... promote virtue, and ... enhance freedom in a distinctive way.").

295. See supra notes 21-22. 
position. ${ }^{296}$ As Professor Melanie Leslie has shown, when a trustee can appreciate the social norms attendant to her conduct, policing that conduct is easier. ${ }^{297}$ In other words, requiring that trustees display integrity helps the trustee understand her obligations. Third, integrity, like competence and candor, helps settlors choose trustees and decide the degree of discretion to confer on them. ${ }^{298}$ The greater integrity a trustee displays, the greater discretion she merits. If the moral component of trust law is "modifiable by contract," or, in other words, not seen as central to the trust relationship, a settlor would have to try to anticipate every possible breach of duty that might arise. ${ }^{299}$ Finally, as noted above, having integrity also means exercising discretion with equal degrees of restraint and courage. ${ }^{300}$ Trustees may opt to embrace the status quo because doing so seems like the most prudent course, but integrity in decision-making sometimes requires more action, more flexibility, or more certainty.

Like a judge, the trustee is charged with maintaining a community of interests, none of them truly her own. ${ }^{301}$ How she appears to the community with which she is involved is therefore intimately tied into her actual job, because her trustworthiness rises and falls with both her personal and professional integrity. We expect judges to display this quality of integrity, because anything short of it undermines confidence in the work they do. For similar reasons, integrity is important to a trustee, even when the trustee is professional, institutional, and feedriven.

\section{Trustee Impartiality and Independence}

Coming full circle, the notion that a decision-maker should be impartial and resist pre-judging is hardly novel but nevertheless provides a useful framework for guiding a trustee to make prudent and responsible

296. Frankel, supra note 10, at 831-32; Leslie, supra note 6, at 90-94.

297. Leslie, supra note 6, at 90 ("To the extent that fiduciary standards embody social or moral norms, deterioration in a common understanding of their meaning will cause a corresponding loss in their proscriptive force." (citing and discussing the work of Melvin A. Eisenberg, Corporate Law and Social Norms, 99 COLUM. L. REV. 1253, 1273-75 (1999))).

298. Frankel, supra note 10, at 831-32 (explaining that an "entrustor may refrain from entering into fiduciary relations unless he perceives the fiduciary as one who will pursue the entrustor's interests.").

299. Leslie, supra note 6, at 93-94.

300. See supra notes $179-83$ and accompanying text.

301. See supra notes 74-78 and accompanying text. 
investments and distributions, especially as time passes and the beneficiaries' circumstances change from what they were when the trust was created. Trustees often distribute assets to beneficiaries in established patterns. ${ }^{302}$ But pre-judgment and inattention to process stunts the functioning of the donative trust; deliberate focus on the parties' respective needs fosters health and longevity in these oftenintimate, long-term relationships. Consider if the Van Dusen trustee had envisioned itself in the role of arbiter, with a judge's corresponding obligations. Whenever the time came to decide whether to distribute principal to Virginia, the trustee-as-judge would not have pre-determined whether a distribution was warranted, but instead would have considered Virginia's needs and assets at that point in time, in light of market trends and other competing interests and the level of discretion and direction the settlor provided in the trust agreement; the trustee then would have disclosed the distribution it decided to make and the reasons for it.

Professor Geyh's three dimensions of judicial impartiality reflect this process and are helpful in parsing out how trustees might approach their roles based on audience. The first dimension of judging, which Geyh has identified as referring to the parties to a case, correlates to the trust beneficiaries who seek a fair process and are "more apt to accept adverse outcomes" if they perceive that they were treated in a way that indicates their matter was not determined before it arose. ${ }^{303}$ Here, then, value derives from a trustee taking time, each distribution period, to review how changed circumstances have affected the trust's directives, investment results, and each beneficiary's needs. Some might argue that this type of deliberation will add costs to administering the trust. In fact, though, this directive provides flesh to the oft-repeated phrase that discretion is judged by conduct rather than results. ${ }^{304}$ Moreover, as noted above, it is hard to imagine that any short-term extra administrative costs that enhance the deliberation process would exceed the long-term damages caused by litigation and any associated transition costs borne by the trust when the trustee ultimately resigns or is replaced. ${ }^{305}$

302. See supra note 113 and accompanying text (discussing Van Dusen distribution pattern). For other examples of imprudent patterns, see Marsman v. Nasca, 573 N.E.2d 1025, 1030 (Mass. App. Ct. 1991); In re JP Morgan Chase Bank, N.A., 956 N.Y.S.2d 856, 857 (N.Y. Sur. Ct. 2012).

303. See supra notes $164-66$ and accompanying text.

304. See Carter v. Carter, 965 N.E.2d 1146, 1156 (Ill. App. Ct. 2012), appeal denied, 968 N.E.2d 1064 (Ill. 2012); Parker v. Shullman, 983 So. 2d 643, 647 (Fla. Dist. Ct. App. 2008); In re HSBC Bank USA, N.A., 98 A.D.3d 300, 309 (N.Y. App. Div. 2012), leave to appeal dismissed, 985 N.E.2d 430 (2013).

305. See, e.g., Wilbourn v. Wilbourn, 106 So. 3d 360, 376-78 (Miss. Ct. App. 2012), reh'g 
The second dimension of judicial impartiality, as Professor Geyh characterizes it, relates to how the public views a judge's decisionmaking process and whether that process reinforces the system's legitimacy. ${ }^{306}$ For trustees, this "political" or more global component of impartiality impacts the larger world of property owners - and potential settlors in particular; every time a trustee is accused of pre-judging a matter or acting on auto-pilot, the utility of the trust vehicle is called into question, regardless of the outcome. For example, in an article entitled Losing Faith in JP Morgan, Two Churches Claim Self-Dealing, ${ }^{307}$ the author describes claims recently filed against the mammoth institutional truste $^{308}$ for investing substantially in its own funds. ${ }^{309}$ Regardless of who ultimately prevails on these claims alleging violations of the duty of loyalty, the trustee's decision to invest a majority of trust assets in its own funds appears to be systematic, based on sheer volume alone, and thus has the potential to undermine public confidence. In contrast, a trustee who takes decision-making seriously by considering distributions and investments at regular intervals and in conjunction with other available options helps inspire confidence in trust planning and thereby serves this larger, "more diffuse" institutional interest. ${ }^{310}$

The third dimension of impartiality relates to the trustee's own vision of her job, her "self-identity." 311 Those who are appointed as trustees are not required to accept the responsibilities. ${ }^{312}$ Indeed, being named to hold and manage a family's ongoing and future financial welfare is an awesome task that requires serious attention; adhering to principles of impartiality may enhance the trustee's self-identity and confirm her position as a decision-maker who cares for all the members of the family without favoritism and prejudgment. So, for example, trustees, even if

denied (Sept. 25, 2012), cert. denied, 105 So. 3d 326 (Miss. 2013) (agreeing that trustee's hostility defeated purpose of trust and justified his removal and describing costs he incurred (and forfeited) as a result of parties' friction)

306. See supra notes $167-69$ and accompanying text.

307. Neil Weinberg, Losing Faith in JPMorgan, Two Churches Claim Self-Dealing, BLOOMBERG BUS. WEEK (Jan. 8, 2015, 4:00 AM), http://www.bloomberg.com/news/articles/201501-08/losing-faith-in-jpmorgan-two-churches-claim-self-dealing.

308. The trustee is JPMorgan Asset Management, "a division that handles funds and trusts [and] managed a record $\$ 2.3$ trillion in client assets at the end of 2013." Id.

309. Most states have statutes allowing a corporate trustee to invest trust assets in mutual funds operated by that trustee. JeSSE DUKEMINIER \& ROBERT H. SitKOFF, WiLLS, TRUSTS, AND ESTATES 593 (9th ed. 2012)

310. Geyh, supra note 147, at 512, 539-40 (discussing how this interest is regulated by mechanisms for judicial removal, selection, and oversight).

311. See supra note $\mathbf{1 7 0 - 7 3}$ and accompanying text.

312. Frankel, supra note 10 , at 833. 
they are members of the family, are entitled to view themselves as professionals and charge "reasonable" fees for their services so that they devote the necessary time to their jobs. ${ }^{313}$ Professional fiduciaries, conversely, should examine whether their tradition of charging by their fee schedules as determined by the assets under management relates in any meaningful way to the effort they expend and the conduct that is expected from them. ${ }^{314}$

Trustee independence, as distinct from impartiality, is another question altogether and arguably exposes the judicial analogy's greatest flaw. A judge should never preside over a dispute that involves her own interests because doing so undermines the credibility of the judicial system. ${ }^{315}$ In contrast, though, many trustees administer trusts in which they are beneficiaries, leading to some of the nastiest breach of duty cases. ${ }^{316}$ A typical example is provided by Carter $v$. Carter, in which the settlor's daughter, who was the trust's remainder beneficiary, sued her step-mother, who was the trust's income beneficiary and trustee, alleging that the step-mother had breached her duties of care and loyalty by investing solely in tax-free municipal bonds. ${ }^{317}$ The trust instrument did not permit the step-mother to receive distributions of principal but authorized her, as trustee, to generate income by investing in any property "regardless of diversification and regardless of whether the property would be considered a proper trust investment." "318 The daughter claimed that her step-mother's investment strategy "failed to protect the principal of the Marital Trust against inflation," thereby

313. ReStatement (Third) OF TRUSTS $\S 38 \mathrm{cmt}$. c (2003); Unif. TRust Code $\S 708$ (amended 2010).

314. See McGrath v. Gallant, 69 A.3d 968, 972 (Conn. App. Ct. 2013) (citing Hayward v. Plant, 119 A. 341 (Conn. 1923)) (describing factors for determining reasonableness of fiduciary fees); In re Gene Wild Revocable Trust, 299 S.W.3d 767, 782 (Mo. Ct. App. 2009) (same); In re Estate of Rolfe, 615 A.2d 625, 628-29 (N.H. 1992) (same).

315. See supra notes $150-52$ and accompanying text.

316. See Donkin v. Donkin, 314 P.3d 780 (Cal. 2013) (sibling beneficiary named as trustee of other siblings' continuing trusts); Carter v. Carter, 965 N.E.2d 1146, 1155-56 (Ill. App. Ct. 2012), appeal denied, 968 N.E.2d 1064 (Ill. 2012) (step-mother named as trustee of step-daughter's trust); Wilbourn v. Wilbourn, 106 So. 3d 360 (Miss. Ct. App. 2012), reh'g denied (Sept. 25, 2012), cert. denied, 105 So. 3d 326 (Miss. 2013) (son and mother both trustees and beneficiaries); In re Matthew Larson Trust, 831 N.W.2d 388 (N.D. 2013) (siblings both trustees and beneficiaries); Shelton v. Tamposi, 62 A.3d 741 (N.H. 2013) (siblings both trustees and beneficiaries); In re Estate of Alden, 35 A.3d 950 (Vt. 2011) (step-mother co-trustee and beneficiary); In re Estate of Cooper, 913 P.2d 393 (Wash. Ct. App. 1996) (father both trustee and beneficiary).

317. Carter, 965 N.E.2d at 1148 .

318. Id. at 1154 . 
eroding the value of the principal in violation of her fiduciary duties. ${ }^{319}$ A sophisticated investor, the step-mother provided evidence that she "evaluat[ed] over the course of time" her investment strategy by "read[ing] the newspapers, the various financial reports, listen[ing] to television, talk[ing] to her friends and her children, who are stockbrokers, et cetera, et cetera., ${ }^{, 20}$ Explaining that the prudent investor rule required the step-mother-trustee "to be mindful of [her stepdaughter's] interests" and to act consistently with those interests "regardless of whether she was acting in good faith or bad faith," the court refused to interfere with the "interested" trustee's exercise of discretion because she did not "act in a wholly unreasonable and arbitrary manner." 321 Whatever can be said about the Carter trustee's discretion, her decision-making certainly challenges the ideal of independence. A judge with this type of interest in a decision's outcome would never be countenanced.

Rather than expose a weakness of the trustee-as-judge framework, though, the questions that the "interested" trustee-beneficiary status raises help reveal one of the analogy's most potent contributions because these concerns help increase sensitivity to trust design and trustee selection. Choosing a loved one as trustee often makes sense because that "interested" person may have the most familiarity with the trust assets, the most sensitivity to family dynamics, or, in the case of a surviving spouse, the most desire and justification for autonomy vis-à-vis assets that are essentially shared property of the marriage, title notwithstanding. Allowing a beneficiary to manage assets that she helped accumulate, subject only to the oversight that fiduciary duties impose on her, often is the best option for achieving the settlor's goals. But a settlor should not abandon the benchmark of independence lightly. Even if she thinks that naming a financially savvy spouse or child to manage assets for her own children or siblings will confer the greatest economic benefit on the trust, this potential advantage must be part of a comprehensive inquiry that also considers the qualities discussed earlier, including the potential trustee's candor, competence, integrity, and impartiality to determine if the sacrifice is worthwhile. Relatedly,

319. Id. at 1149 .

320. Id. at 1150 .

321. Id. at 1158; see also Cooper, 913 P.2d at 401 (exercising "wide latitude of discretion" to remove family trustee from administering sister's trust, though he stayed as trustee of his own separate trust, because, "[g]iven the relationship between these parties, retaining [him] as trustee only insures more litigation."). 
trustee-beneficiaries can best segregate their interests and maintain their independence as trustees by adhering to these ideals. Even a truly "independent" - in other words, disinterested - trustee, who initially may cause the beneficiaries to have more trust in her decision-making, because she is independent, will fail if she does not display the other judicial qualities described above. ${ }^{322}$ And if the settlor decides that the benefits of naming an "interested" trustee outweigh its costs, a solution may be to divide the duties among co-trustees. ${ }^{323}$ By directing attention to the importance of independence and the trust that is eroded when that independence is sacrificed, the trustee-as-judge paradigm can enhance trust creators' ability to anticipate and design plans that have a chance of operating smoothly on into the future.

\section{CONCLUSION: TOUCHSTONES OF TRUST}

A black siliceous stone that was once used to test the purity of gold, a touchstone, has come to mean "something that is used to make judgments about the quality of other things." 324 In thinking about the challenges that are posed by private donative trusts, the judicial process provides an apt touchstone for trustee decision-making. An ideal judicial process prioritizes candor, competence, integrity, and impartiality, which together emphasize relationship and procedure ahead of actions and results. So too do these qualities provide some guiding principles for those seeking to facilitate the way that trusts function in the lived world. In other words, the qualities that make for principled adjudication can help trustees accomplish their investment and distribution directives, help settlors (and their estate planners) better select trustees and guide their conduct, and ultimately help enhance beneficiaries' trust in the trustee's exercise of her discretion.

322. See Frankel, supra note 10, at 822-23 (describing how deference to "a trustor's appointment of a family member as trustee even when the latter has a conflict of interest" makes sense "because the trustor is probably in a better position to evaluate the wisdom of the appointment. But when a conflict of interest arises in circumstances that the trustor could not have anticipated... confidence in the trustor's judgment may weaken ....").

323. See Shelton v. Tamposi, 62 A.3d 741, 746 (N.H. 2013) (naming two of six children as "investment directors," because they were involved with family businesses, and a separate independent trustee); In re Chantarasmi, 938 N.Y.S.2d 762, 766 (N.Y. Sur. Ct. 2012) ("[B]y requiring that three trustees serve, two of whom are independent, the parties' sought to ensure that the trust funds would be administered fairly and impartially.").

324. Touchstone Definition, Merriam-Webster's COllegiate Dictionary, http://www.mer riam-webster.com/dictionary/touchstone (last visited Apr. 22, 2015). 